
ANALYSIS BASED ON THE PRIMING EFFECT

\author{
Maria Naftally Dantas Barbosa \\ Master, Universidade Federal Rural do Semi-Árido - UFERSA \\ Mossoró, RN - Brazil \\ naftallydantas2@gmail.com \\ Yákara Vasconcelos Pereira \\ Doctor, Adjunct Professor at The Universidade Federal de Pernambuco - UFPE \\ Recife, PE - Brazil \\ yakarav@gmail.com \\ Karla Rosane do Amaral Demoly \\ Post Doctor in Education UMINHO PT \\ Associate Professor at Universidade Federal Rural do Semi-Árido - UFERSA \\ Mossoró, RN - Brazil \\ karla.demoly@gmail.com
}

Abstract

Objective: This investigation aimed to identify the positive and negative attributes of Instagram posts and their ways of leading to consumption.

Method: A case study was carried out with users of Instagram in two steps: through group and individual interviews. A total of thirty-three subjects took part in the semi-structured interviews that were analyzed through content analysis with the support of the ATLAS.ti software.

Originality/Relevance: An investigation into Instagram as an online tool to influence consumer behavior is necessary, since it is one of the online environments that are now building and maintaining social relationships that influence contemporary society.

Results: The results showed that publications with high quality images, happy people, good presentation of the product/service, real and positive experiences and complementary information are the positive attributes. On the other hand, publications with unattractive and poor-quality images, which do not correspond with the reality of the product/service or do not correspond with the reality of the user, with disguised advertising and without information, constitute the negative attributes. Also, it is noticed that the publications lead to consumption in different ways, however, this occurred through preexistent mental representations.

Theoretical/methodological contributions: This paper presented a discussion about the theme of the activation of consumption on Instagram, which is still little explored in the consumer behavior literature. In addition, it portrays characteristics of publications that lead to positive and negative effects on the view of respondents who represented each state in Brazil.

Keywords: Activation of consumption. Instagram. Posts' Attributes. Consumer behavior.

How to cite the article

American Psychological Association (APA)

Barbosa, M. N. D., Pereira, Y. V., \& Demoly, K. R. do A. (July/Sept. 2020). Instagram and its consumption attributes: a content analysis based on the priming effect. Brazilian Journal of Marketing, 19(3), 560-585. https://doi.org/10.5585/remark.v19i3.13907. 


\section{Introduction}

In addition to facilitating and expanding communication channels between users, internet technologies have stimulated public involvement in the observation, selection, interpretation and sharing of information (Primo, 2007). In this context, it is through mediated conversation that informational exchanges are established, giving rise to internet social networks or digital social networks (Recuero, 2009).

Despite being more part of the lives of young people, social networks can influence the consumption behavior of people of different ages (Harris \& Dennis, 2011), which makes their impact even greater. In addition, this practice of recommendations, sharing opinions and advice related to consumption can generate confidence and negatively or positively influence the purchase intention (Tubenchlak, Faveri, Zanini, \& Goldszmidt, 2015; Solomon, 2016).

One of the fastest growing social networks worldwide is Instagram (Djafarova \& Rushworth, 2016). The application was founded in 2010 and allows users to capture and share images and videos online instantly. Among the network's functions, it is possible to highlight the users' ability to add descriptions, hashtags, mention other users and insert locations and links in their publications (Hu, Manikonda, \& Kambhampati, 2014).

In the case of Instagram, people are divided between followers (profiles that follow the user) and followed (profiles that the user follows). This resource constitutes the user's network of contacts, allowing him to be followed and follow profiles of acquaintances, personalities and even other people, who are interested in following the content (Hu et al., 2014), being able to like their favorite posts, leave comments and share content, including consumption information (Guimarães \& Gouveia, 2015). Thus, it is understood that the social network in question facilitates communication between consumers, increasing the potential for sharing personal consumer experiences in real time and in different devices and formats (Tubenchlak et al., 2015).

It is worth mentioning that the consumption recommendations, as well as the preference for a certain product, service and brand disseminated through messages mediated by social networks, have significant effects on judgments and on a possible purchase decision by users (Di Pietro \& Pantano, 2012), aspects that can contribute to activate consumption.

The activation process is a recurring aspect of the priming effect (Minton, Cornwell, \& Kahle, 2016), consisting of tactics of influence and persuasion that trigger certain automatic conscious (intentional) or unconscious (unintentional) responses (Dijksterhuis, Smith, Baaren, \& Wigboldus, 2006). It can be described as a set of external stimuli that lead to the activation 
of some concept, idea and stereotypes, by presenting a specific object or situation, causing subsequent behavior in individuals (Fazio, Sanbonmatsu, Powell, \& Kardes, 1986; Martin \& Morich, 2011). Above all, priming effects can be responsible for activating or altering consumers' perception and behavior, as well as their attitudes and beliefs through factors within and outside conscious control.

Furthermore, it is important to emphasize that activation can foster two perceptions about the stimulus on the user: positive, when the user identifies himself with the post and wants to be aligned with the characteristics of what is being exposed; or negative, when there is no identification with the post, making the user to avoid the characteristics of the stimulus (Galvão, Lucena, \& Prado, 2016). This reinforces the idea that the attributes of images published on Instagram can be decisive to increase or compromise the popularity, recognition and confidence of products and brands (Jin \& Ryu, 2019), facilitating users' purchasing decisions.

Despite being a subject belonging to the current context of society, the amount of research that addresses the persuasive aspects present on Instagram posts that influence consumer behavior is incipient, being essential to expand the studies on the subject (Veirman \& Hudders, 2019). In general, an investigation on Instagram as an online tool to influence consumer behavior is pertinent and necessary, since this platform is currently an environment for building and maintaining social relationships and consumer involvement, and that, for these reasons, can stimulate the activation of users' consumption (Chu \& Kim, 2011).

Thus, we seek to fill this theoretical gap and present these known aspects, also showing how users respond to the display of posts and how they can affect consumers' decisions. Therefore, this investigation aims to identify the positive and negative attributes of Instagram posts and their ways of activating consumption.

\section{Theoretical framework}

In this section, the theories that were the basis for the development of this study are presented.

\subsection{Consumer behavior in digital social networks}

Studies involving consumer behavior have been constantly addressed in recent decades, as it is an area that is always evolving as new habits, lifestyles and forms of interaction emerge (Solomon, 2016). Consumer behavior is a field that studies purchasing 
behaviors (Rani, 2014), addressing the mental, physical and emotional activities of the subjects involved in the consumption process (Mashhadi \& Hashemiamin, 2017), as well as the individual actions and experiences that can come to influence decision-making (Badgaiyan \& Verma, 2015; Silva \& Rabelo Neto, 2018) and consciously satisfy their needs.

Consumer behavior is not limited to the moment of purchase, when there is the exchange of money for the product. The understanding is broader and involves the entire consumption process, including aspects that influence the consumer before, during and after the purchase (pre-purchase, purchase and post-purchase). It is noted that to better understand the consumer, it is necessary to know the context in which he lives and the environment in which he is inserted, such as the aspects that involve the communities (Solomon, 2016; Silva \& Rabelo Neto, 2018), as an example of the influence from the internet.

With the spread of the internet, online communication tools have expanded, increasing the availability of information exchange and facilitating the construction of relationships and socialization among users (Peppard \& Butler, 1998). This phenomenon took on an even greater proportion with the appearance of virtual communities, launched in 1997, by enabling users to start expressing their opinions and making purchase decisions (Boyd \& Ellison, 2008). However, these changes occurred not only in the interaction between consumers, but also between potential buyers, stimulating dialogue between peers (Ioanăs \& Stoica, 2014) in a faster, more accessible and instantaneous way.

Specifically on Instagram, it is noticed that the photo sharing tool makes the social network the consumers' favorite one to share things (Alhidari \& Paswan, 2015; Ting, Ming, Run, \& Choo, 2015), since the posts with product photos allow users to acquire information before making a decision (Kusumah, 2015), reducing the perceived risk when making a purchase (Djafarova \& Rushworth, 2016).

It is important to clarify that these publications have some aesthetic attributes that may be responsible for speeding up the consumption process by users, when considering that the appearance of an image published on social networks is directly related to the increasing desire to buy and, consequently, to the success of the product or service being exposed (Moreira, Jacques, \& Pizzato, 2019).

On the other hand, attributes are defined as the symbolic and physical characteristics of a particular product or situation capable of satisfying or not meeting consumer expectations (Rodrigues, Araújo, Castro, \& Castelo, 2019). In this case, it is understood that the attributes 
of the posts can stimulate the process of positive or negative activation of consumption. This activation process is related to the priming effect, a theory portrayed in the following topic.

\subsection{Priming effect}

Human beings are constantly influenced by the social environment in which they live, the people they live with and the objects they intend to reach. As a consequence, these exposures can affect the behavior of individuals, encouraging them to perform a subsequent reaction in response to the stimulus (Pacheco Junior, Damacena, \& Bronzatti, 2015; Solomon, 2016). This reaction process is called priming.

From the perspective of consumer behavior, Solomon (2016, p. 58) highlights that priming is part of the consumer's usual decision making, which refers to "[...] the choices made with little or no conscious effort". This process occurs through associations between a stimulus and factors related to it (Fazio et al., 1986), that is, when an individual is exposed to a specific stimulus, such as images that refer to products and brands, the idea of consumption is automatically activated, leading to the assumption of subsequent behaviors. These behaviors can be the act of purchasing the product, in cases of positive activation or rejection of the product, in cases of negative activation (Galvão et al., 2016).

The effects priming may influence on the behavior formation, perceptions and judgments of individuals, even if they are not perceived. These can be visual, auditory, olfactory and can temporarily activate a response trend (Tate, Stewart, \& Daly, 2014; Nicolao, Yorkston, Brocato, \& Brei, 2016). Therefore, the priming causes an activation through three forms, namely: affective or emotional; behavioral or motivational; and cognitive or semantic.

Affective priming involves unintentional stimuli, such as feelings and emotions related to an idea. Most of the time the effect occurs with images and colors, for example, symbols related to love and colors that represent joy. In addition, images are responsible for producing more affective stimuli than words, because they appeal to the senses and less to rationality (Tate et al., 2014; Minton, Cornwell, \& Kahle, 2016).

Behavioral priming involves behavioral intentions that are activated through information that is kept in memory and is only associated when the individual is faced with the object or context (Pacheco Junior et al., 2015). An example of this, in the context of consumer behavior, is the motivation that an individual receives to perform the purchase of a high quality and socially accepted product right after seeing the Apple logo or when he starts 
to have healthier habits when being constantly exposed to gym advertisements or posters with vegetarian recipes (Minton et al., 2016).

Finally, cognitive priming refers to changes in thinking based on the presence of a stimulus. It is also known as a semantic activation, as it can be driven by words, phrases, signs, symbols, which influences a response/action. In the fields of marketing and consumer behavior studies, cognitive and semantic activation is used to measure what the consumer thinks after he has been exposed to a stimulus (Minton et al., 2016), namely, the consumer's assessment about the brand or product and their personal experiences.

Another type mentioned by Pacheco Junior et al. (2015) and Dijksterhuis et al. (2006), social priming is constituted by representing social actions of people and can be considered as an activating stimulus. In this case, people associated with other people can be led to the automatic activation of an action, for example, when observing the behavior of relatives, friends and important people, the individual begins to act like these people and have the same consumption habits (Dijksterhuis et al., 2006; Meurer, Medeiros, Dal'maso, \& Holz, 2010).

It is still important to clarify that a stimulus alone is not able to generate an action, requiring pre-existing mental representations for the idea to be activated (Galvão et al., 2016), that is, the individual must already have an internalized consumption interest so it can be, in fact, activated after exposure. Thus, Instagram can influence the activation of consumption through different types of posts, such as images, videos and comments. In order to confirm this thought, Mirsch, Lehrer and Jung (2017) analyzed photos of users of the social network and found that images published by followed profiles sharing moments, opinions, product demonstrations and brand recommendations may activate consumer interest, stimulating one to make the decision to consume, what will be covered on the next topic.

\subsection{Activating attributes}

Another important aspect that must be discussed is in relation to the different types of publications that Instagram provides, such as images, videos and comments, which can influence the activation of consumption. This user-generated content is what daily feeds the network and makes it attractive (Obar \& Wildman, 2015). In social networks like Instagram, each user has a timeline considered as a space containing an updated list of their main connections of interest, such as the posts and content sharing of the profiles that they follow (Ferreira, Constantino, \& Lima, 2017). 
The main resources available on Instagram include comments, photo sharing, location feature, in addition to publications in video format (Yen, 2017), as will be better addressed below.

The interconnectivity between consumers of social networks like Instagram is demonstrated through comments (Astuti \& Putri, 2018). About this resource, Gössling and Stavrinidi (2016) carried out an analysis on Instagram posts and found comments with short and positive messages, most of the time, conveying admiration and the desire to also acquire what was published by the followed contacts. This suggests that comments with statements about products and services on Instagram can develop a positive attitude and consumerfriendly behavior in users (Miranda, Rubio, Chamorro, \& Loureiro, 2014; Djafarova \& Rushworth, 2016; Kreft \& Karwat, 2017), bearing in mind that users will be more likely to buy after reading positive reviews (Yogesh \& Yesha, 2014).

It is understood that the main feature of Instagram is the capture and sharing of images, offering users the unique way of posting photos and videos using smartphones and applying different manipulation tools (Hu et al., 2014; Guimarães \& Gouveia, 2015). The photo post has been an influential tool in the formation of identity, as a way of selfdisclosure, as well as sharing experiences and new products that they acquire. It was possible to find two reasons for analyzing the photo posting in the behavior of Instagram users: the first is related to the visual excitement that the photographs transmit to users, being able to offer more information than text publications; the second reason is the need that people have to expose their everyday life on social networks, particularly with a more select audience (Guimarães \& Gouveia, 2015; Yen, 2017). It is noteworthy that publications with images on social networks can be a prominent stimulus in the activation of consumption, because the visual exposure of objects causes an increase in the perception of trust between individuals, making the user pay more attention to the content (Hsu, 2015; Jin \& Ryu, 2019).

Regarding the third instrument, Yen (2017) indicates that the feature of checking the location (check-in) in photos stimulates the users' action, affecting their consumption intention, mainly of trips and restaurants. It is important to emphasize that this action is triggered by aspirational consumption, which occurs as a result of a social comparison between users ( $\mathrm{Liu}, \mathrm{Wu}, \& \mathrm{Li}, 2018$ ), making posts with location together with a photograph and an attribute of the place mentioned, arouse "imaginative envy" or "benign envy", that is, it makes the observer imagine the situational context and also be interested in getting to knowing it (Gössling \& Stavrinidi, 2016; Liu et al., 2018). In this context, it is important to 
clarify that this envy is only considered a positive feeling as long as there is no intention to generate competitiveness with the profiles followed (Liu et al., 2018).

Finally, in 2016, Instagram launched Insta stories mode, a dedicated resource for users to instantly share their stories and experiences in the form of photographs, videos and texts (Silva \& Rabelo Neto, 2018). The feature is known as ephemeral message, due to the fact that it is available in the user's profile for only 24 hours, with the need for the content to be constantly renewed (Ferreira et al., 2017). This function can also be responsible for awakening the users' purchase intention by making images with products, services and brands experiments available spontaneously (Damayanti \& Pamungkas, 2018).

Regarding the specificities of the content provided, it was found that the quality of the information perceived influences the purchase intention of the message recipients, becoming a crucial factor to arouse interest, generate consumption preferences and increase purchase options (Toor, Husnain, \& Hussain, 2017). Because Instagram is a social network focused on images, it focuses on the visual and aesthetic of the content, encouraging users to share only positive content (Djafarova \& Rushworth, 2016; Guimarães \& Gouveia, 2015), such as photos by their healthy, happy and photogenic moments (Jacob, 2014), avoiding revealing other products to which they are not satisfied . Considering what has been presented, it is clear that these factors present in digital social networks can contribute to stimulate the desire of consumption of network users through the publications of the profiles they are following.

\section{Method}

For this investigation, we decided for a qualitative approach, which seeks to understand a phenomenon, based on the collection of information, interpretation and description of subjects and their context (Stake, 2011; Godoy, 1995). According to Cooper and Schindler (2011), qualitative research aims to achieve a deep understanding about a specific situation or the interaction between people (individuals or groups) and things. Thus, the approach is adequate for the study, since the investigation is centered on human behavior, extracting data about the feelings, motivations and perceptions of each subject studied and not only presenting a general aspect (Cooper \& Schindler, 2011).

To obtain the information in order to achieve the research objective, it was decided to conduct a case study, conceptualized by Yin (2015) as an empirical research, carried out in a detailed and in-depth way on a contemporary theme. Case studies focus on a situation, event, 
program (Merriam, 1988) or more complex individual, group and organizational phenomena in society, such as the study of the behavior of small groups in particular. In addition, it favors a greater level of detail in the relationships between individuals and the context, as well as dealing with more subjective information and greater wealth of details (Yin, 2015).

Thus, the case study method is appropriate for this investigation, as it considers that it contributes to facilitate the understanding of specific processes and to examine in detail the response of the consumer to a given stimulus (Cooper \& Schindler, 2011).

Since this is a case study, semi-structured interviews (Copper \& Schindler, 2011) were used as a data collection technique, as it is considered "[...] a fundamental qualitative research strategy" (Godoy, 1995, p. 61). Then, this research used two types of interviews, being carried out in two distinct stages: group interview and individual interview, in order to obtain detailed information about the phenomenon.

Prior to the data collection period, a pilot study was carried out with two subjects, one from Rio Grande do Norte and the other from Ceará, on September 18, in Mossoró-RN, with the aim of validating and improving the scripts interviews of the two stages, that were designed based on the theoretical framework. The pilot study was of great help to the development of the following procedures (Yin, 2015), that included the reworking of questions and the inclusion of new topics to be addressed (Leite, Moraes, \& Salazar, 2016).

It is important to highlight that both interviews followed scripts with open questions. The scripts contained the same questions, however, in the script for the individual interview, questions with more specific content were added. At the time, the interviewees were asked about Instagram's relationship with their consumption in general, the social network resources they liked the most and the aspects that led them to be interested in or reject a particular publication and its content. They were also asked about the feelings, emotions and behaviors that are aroused when viewing the post and being exposed to the product, service, person or information.

Thus, the group interview was conducted in the first stage of data collection, on September 27, 2018, with a group of 6 people to obtain a wide variety of information (Cooper \& Schindler, 2011). The interview lasted about 1 hour and 24 minutes and was conducted by one of the researchers in order to carry out the mediation and record the information through two recorders that were used to collaborate in the interview transcription afterwards.

To participate in the group interview, the following criteria were determined: (a) being over 18 years old and (b) being a user of Instagram. As a result, the interview was composed 
of 6 heterogeneous subjects, with a variety of opinions, life history and different behaviors (Cooper \& Schindler, 2011), being a total of 3 women and 3 men, aged between 21 and 39 years old, being 5 respondents from Rio Grande do Norte and 1 from Ceará. They were all students of the Advertising undergraduate course at the State University of Rio Grande do Norte and work in the communication field, allowing access to the addressed topic.

As a way to expand the responses and obtain more specific and detailed information about the users' experiences on Instagram, the second stage was carried out, consisting of an individual semi-structured interview with 27 people from each Brazilian state, in isolated moments and pre-scheduled times. In order to reach all subjects of the research, the interviews took place in person, online, via Skype and Whatsapp, and also by phone, and were also recorded, reaching a total of 684 minutes.

In order to participate in the individual interview, the following criteria were determined: (a) over 18 years old; (b) user of Instagram; (c) the participants should have been born in different Brazilian states. The last criterion mentioned was fundamental to expand the study of the phenomenon under analysis. Therefore, 21 women and 6 men, aged between 18 and 50 years, were interviewed. Respondents still have different levels of education and profession/occupation, which contributes to the scope and differentiation of the responses collected.

It is important to clarify that the criterion for selecting the subjects was snowball sampling, which uses chains of reference from existing participants (Flick, 2009). Thus, the interviewees indicated new contacts from their personal network with the desired characteristics to participate in the interviews. The exact number of participants in the individual interview sessions was defined when information saturation was obtained, which occurs when there is no more news in the responses collected (Paiva Junior, Leão, \& Melo, 2011). In this research, it occurred when the subject of the last state was interviewed.

After the data collection phase, the analysis, considered by Gomes (2001) as the stage of data treatment and interpretation of the results obtained, started. In this research, the content analysis technique was adopted to perform data interpretation, assisting in the description, inference and interpretation (Bardin, 2011) of the data, seeking to obtain connections with the theoretical framework addressed in the research.

The analysis of open questions, such as those that were applied in the interview sessions, helped to understand the relationships that individuals have with the object of research, in the publications of Instagram (Bardin, 2011). The choice for this method of 
analysis is justified by the need to enrich reading by understanding the meanings and by revealing the relationships established in the speech or writing of the interviewees (Cavalcante, Calixto, \& Pinheiro, 2014).

Also, according to Bardin (2011), data analysis was composed of three fundamental steps: pre-analysis, material exploration and treatment of results. Pre-analysis is considered to be the organizational phase. In this stage, the scope of the research was defined and a rereading of the material was carried out, in order to remove the typos and language addictions of the respondents.

The exploration of the material is the management phase of the decisions made in the pre-analysis. It consists of in-depth reading of the material, seeking to code, classify and categorize (Bardin, 2011). It is worth noting that at this stage, at the time of coding, some constructs were raised to enrich the analysis. In order to do this, the delimitation, which corresponds to the choice of registration units, was defined, leading to the selection of keywords and recurring themes (Bardin, 2011).

The last step corresponds to the treatment of the results obtained and interpretation. For Bardin (2011), this is the phase of treating the data in a way that is meaningful and valid. It uses qualitative and/or quantitative techniques to help in the interpretation, seeking to confirm the assumptions of the research and achieve the initially proposed objectives. Thus, networks were used in this research to assist in the interpretation of results.

It is important to emphasize that in the data analysis stage ATLAS.ti was used in version 8 . This is a tool that contributes to the conduct of research that applies content analysis (Walter \& Bach, 2015). Among the functionalities of ATLAS.ti there is the treatment of a high amount of information, which facilitates its operation and, consequently, the work of the researcher (Leite, Moraes, \& Salazar, 2016), as it makes the process more agile. With the program, it was possible to access the transcripts, analyze, code and categorize the participants' responses.

\section{Analysis of results}

This section assumes that the quality of the published content arouses interest and influences both positively and negatively the recipients' purchase intention (Toor et al., 2017). Thus, according to the respondents' responses, it was possible to list the positive points of the publications that activate consumption and arouse interest in purchase, namely: posts with 
high quality images; publications with happy people; publications with a good presentation of the product/service; publications with real and positive experiences and publications with complementary information (see figure 1).

Figure 1 - Positive Attributes

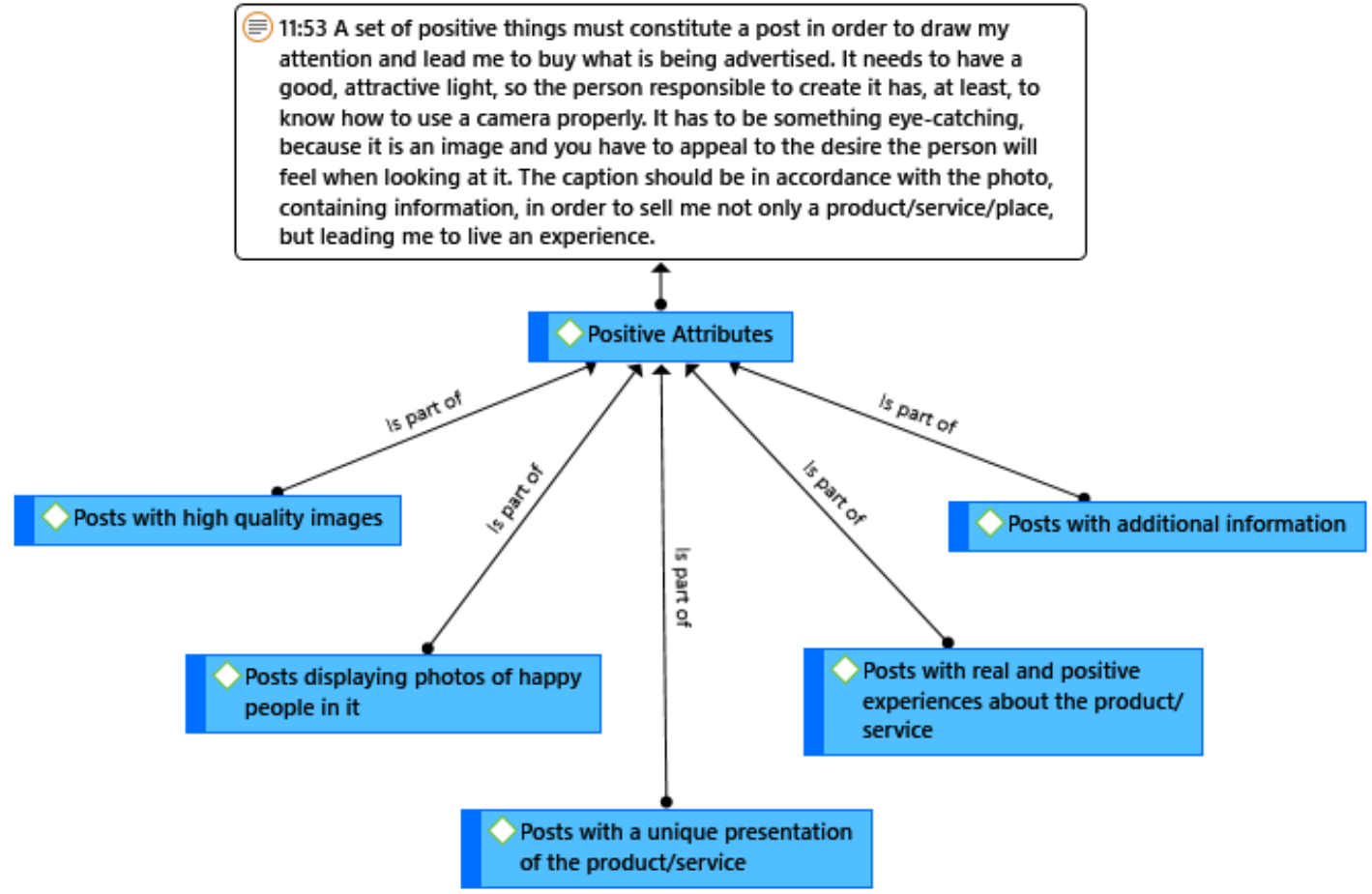

Source: Authors' elaboration using ATLAS.ti (2019).

The first attribute considered positive by the interviewees is formed by posts with high quality images. They were described as clean, organized images, with vivid colors, high resolution and sharpness. This attribute is considered a strong point to attract the user's attention to the post (Interviewee 6), being responsible for selling the content at the first instant (Interviewee 18_MA), motivating the purchase (Interviewee 1 and Interviewee 5). This reinforces the idea that well-designed posts positively activate consumption, since the visual display of products/services is aesthetically attractive and increases the level of user's confidence (Hsu, 2015; Jin \& Ryu, 2019).

Regarding the second positive factor, it is possible to identify posts with happy people. Respondents mentioned that in addition to the attractive image, the fact of expressing happiness is also an attribute that arouses curiosity and a desire to feel like the people in the image are feeling, as Interviewee 20_AL reported: “A very clear, colorful image and if there is a person on it I pay attention to their countenance. If they are happy, if it is a fun moment. So, the way the person is in the photo also catches my attention". This result reaffirms the 
authors' thinking, with regard to the positive content shared by users, namely, photos of happy moments of the followed contacts have a greater impact, as they generate in users the need to purchase the same product or visit the same place in order to follow the pattern of happiness that was published (Jacob, 2014).

The third factor mentioned refers to posts with differentiated presentation of the product/service. Here, the object is not presented directly, but inserted in context. In this regard, it was possible to notice that users are attentive to the way the object and the person are exposed in the image, prioritizing the most natural, spontaneous and authentic presentation, with no intention of selling. "I like creative posts, where the product is exposed in a different way. I think it's not just taking the picture of the product itself, but exposing it in a different, natural and not forced context just to sell or to show that you have it." (Interviewee 14_MT). This report strengthens the understanding of Guimarães and Gouveia (2015), because despite the fact that there are numerous image manipulation features available on Instagram, like the filters, the photos on social networks are a representation of reality and, therefore, influence the behavior of users.

It is important to notice that this attribute is in accordance with the following factor, which deals with posts with real and positive consumption experiences. Regarding this aspect, it is observed that users search for true experiences of people who have actually bought and used the product and share a positive consumption story (Interviewee 30_GO). This finding is in accordance with Miranda et al. (2014), Djafarova and Rushworth, (2016) and Kreft and Karwat (2017), since they understand that the reports of positive consumption experiences of the followed profiles impact on the purchase decision of users, especially those who are in a phase of searching for information.

Finally, respondents mentioned posts with complementary information as the fifth positive factor. It was reported that users prioritize publications with more information about the product/service, such as price, times and address, since they facilitate the apprehension of the content and streamline the process, as explained by Interviewee 1: “[...] if it's food, I want it to have a price, because I like something more practical, so if I know the price and the address, it works for me, I don't need to look for more information, I just buy it". This reinforces the idea that users seek the posts of the profiles they follow to find out more about their products before making a decision, intending to feel more confident about the purchase (Djafarova \& Rushworth, 2016). These data demonstrate the importance of social networks 
such as Instagram in the daily lives of consumers, for encouraging discussion and sharing of content among users (Alhidari \& Paswan, 2015).

In addition to the positive attributes, it is noted that activation can occur in the opposite direction, leading the individual to want to distance himself or avoid the characteristics of the stimulus, if there is no identification (Galvão et al., 2016). Therefore, it was possible to identify five negative attributes, considered undesirable by the interviewees: posts with unattractive and poor quality images; posts that do not correspond to the reality of the product/service; posts that do not correspond to the user's reality; posts with disguised advertising; and, advertising without information (see figure 2).

The first negative aspect is related to publications with unattractive and poor quality images. Respondents reported that images that are unclear or that are aesthetically polluted, with excessive information and poor product presentation do not attract their attention and cause them to ignore the published content (Interviewee 11_CE). This data reinforces Jacob (2014), in the sense that there is an overvaluation of perfect images of desired situations on Instagram, leading users to not pay much attention any image that is aesthetically unsuitable.

Figure 2 - Negative Attributes

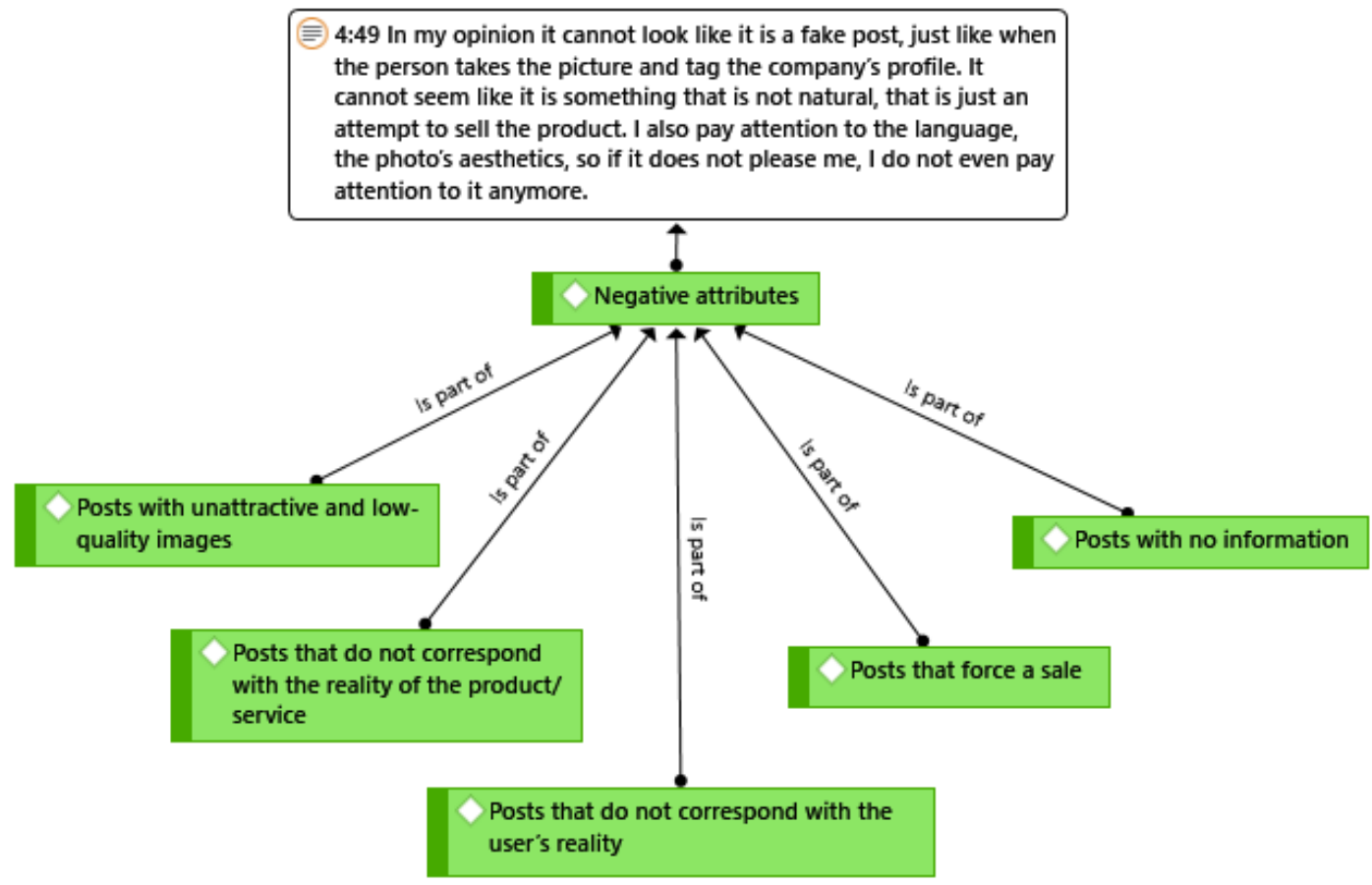

Source: Authors' elaboration using Atlas.ti (2019).

Another negative factor cited by the interviewees refers to posts that do not correspond to the reality of the product or service, namely, posts that share false images and deceive users, as detailed by Interviewee 10_SC: "I see an over edited post as negative, out of reality, 
because sometimes we see a product on Instagram and when you decide to buy it, you see that it is totally different from what was posted". In this regard, it is understood that significant manipulation of the image can increase the perceived risk at the time of purchase, and may lead the user to make mistakes (Djafarova \& Rushworth, 2016), thus causing this post to be discarded.

Still in this regard, it was reported that posts outside the user's reality are also portrayed as a negative aspect, because these posts show products that are out of budget, in addition to promoting a lifestyle different from which users live. This understanding is confirmed through the opinion of Interviewee 14_MT:

\footnotetext{
I usually lose interest when the photo escapes my reality. When a person wants to show too much perfection, a perfect body, wealth, pageantry. Sometimes it seems forced and dull. It ends up not drawing my attention, because it is out of my reality, I know I will not use that product that way.
}

In this report, it was possible to identify the presence of dissociative groups, which individuals do not wish to be associated with. This is because when those who they are following post something that does not match their reality, values and behaviors, users tend to withdraw and reject the content, damaging the influence process (Meurer et al., 2010).

As for publications with disguised advertising, the interviewees mentioned as a negative factor those in which people force a sale, showing the product, the price and the store intensely, without informing the product's differentials and situations in which it could be useful (Interviewee 27_AP and Interviewee 30_GO). Thus, the results are in line with the literature by revealing that for a received message to be accepted, users tend to analyze it according to the usefulness of the information and how much that message can help in the decision, rejecting any forced information, without arguments or credibility (Nunes, Ferreira, Freitas, \& Ramos, 2017).

In the same sense, it was mentioned by the interviewees that posts without a description of the product and service are not well accepted, since users search for information to make the purchase (Miranda et al., 2014; Zucco, Pianezzer, \& Falaster, 2017). Therefore, it is worth saying that the post that does not add more information that facilitates the user's decision tends to be ignored and exchanged for another post with more complete content, as Interviewee 15_DF pointed out: "I don't like a post without any information. If there is nothing in it, I just move on and start looking for information elsewhere". 
Thus, it was possible to observe that Instagram posts influence consumption through different attributes (Mirsch et al., 2017) that can activate a response motivated by emotional, behavioral, cognitive and personal issues (Tate et al., 2014; Nicolao et al., 2016).

After identifying the positive and negative attributes of the posts that lead to the activation, it was possible to verify the resources present in the posts that attract users the most at the moment that the stimulus is exposed. And even more deeply, it is possible to understand how the activation of consumption occurs on Instagram, and how it can influence the emotions, intentions, actions and perception of people present in this social network. Figure 3 shows the network that explains this situation, involving the posts that most attract users and the forms of activation.

The first resource mentioned was the photo post, a format that users use the most when they want to analyze the context of the image, observe the posted products, seek inspiration and trends, in addition to following the profiles that are of interest and interacting with them, as explained by the interviewee.: "On Instagram I like more when the photos are posted on the feed, because it is there, we can enjoy, comment, participate in the moment, interact. The image is the most important thing on this social network" (Interviewee 9_SP). This result comes to confirm that the sharing of images is the main feature of Instagram, considering that photography provides visual enchantment for those who view it, raising the level of desire for what is being disclosed (Hu et al., 2014; Guimarães \& Gouveia, 2015; Yen, 2017). 
Figure 3 - Ways to activate consumption

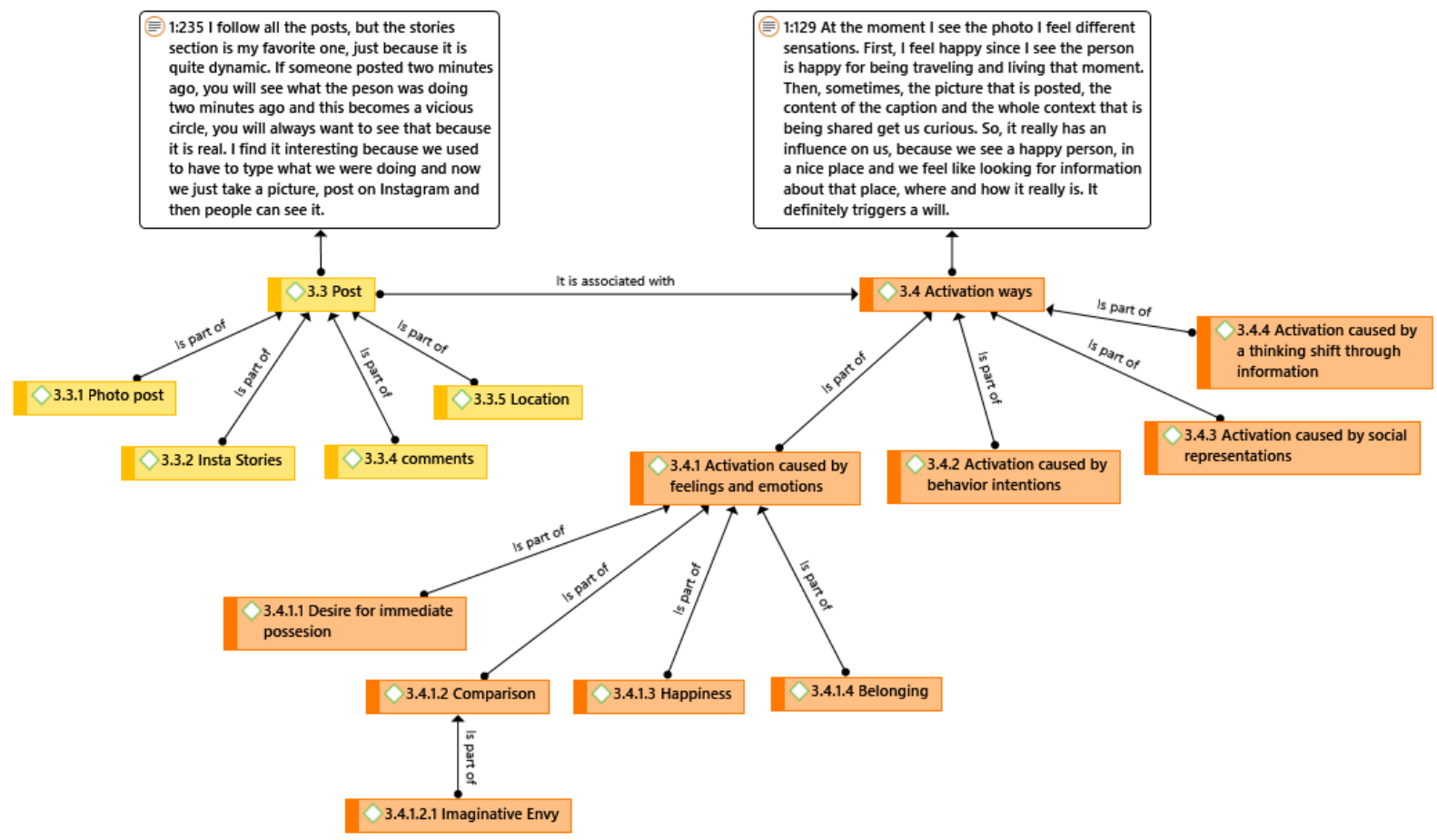

Source: Authors' elaboration using Atlas.ti (2019).

On the other hand, Insta stories was the resource most often mentioned by respondents, as it is seen as a more dynamic, fast and accessible publication. The differential of Stories is in allowing users to follow almost in real time what the people who they follow are doing, improving the interaction and socialization between them (Interviewee 16_SE).

Thus, it is clear that through Insta stories, users are encouraged to interact and view new content continuously from their contacts, and it encourages them to feel the need to always be following what they are doing, the places they go to, the food they ask for and what they buy, enhancing the purchase intention due to the excess of content to which they are exposed all the time (Damayanti \& Pamungkas, 2018). Also, the results reinforce the thought of Ferreira et al., (2017), in what regards Stories' reliability, since, according to the interviewees, this feature shows the real life of their virtual contacts spontaneously, helping to increase trust (Interviewee 21_BA and Interviewee 27_AP).

Regarding the comments, it is understood that users usually observe the opinion of the people who comment on the posts, as a way to prepare and inform themselves before making a purchase or visiting a specific place (Interviewee 21_BA), confirming the idea that the opinions of virtual contacts about products and services motivate a positive or negative 
attitude towards consumption, depending on the experience that was shared on the social network (Djafarova \& Rushworth, 2016; Kreft \& Karwat, 2017).

As for the locations, the interviewees say they are attracted to the places where contacts post photos, especially if they are unknown. It was possible to notice that the feature of checking the location stands out among users who search for information or are predisposed to travel content, as described by Interviewee 14_MT: "I love to travel, so it happened that a friend posted a photo in a very beautiful city, what caught my attention, so I've been looking at the location and then used Google Maps to gather more information, what made me get interested in going to that place." This finding is in accordance with the literature, as it is an aspirational consumption: when viewing the photo with the location checking, the user feels the desire to also go to that place, triggering the purchase action as a consequence (Yen, 2017; Liu et al., 2018).

With regard to the forms of activation present on Instagram posts, the presence of affective, behavioral, social and cognitive activation was identified. According to the respondents' responses, it is noted that users are most often attracted by the posts of those they follow due to the feelings that are triggered when they are exposed to the stimulus. In this case, when viewing the images, users aspire to be in the place of their contacts, experiencing the same experience of feeling the sensation of pleasure and happiness that is exposed. This influences their desire for consumption, leading them to purchase the product/service due to emotions, as stated by Interviewee 23_ES:

I think my friends influence me through the sensations that I feel when seeing a certain post, for example, of a new pair of sneakers that you associate to that kind of emotion, that kind of experience the person is going through and then you just want to feel the same way. So, it is somehow this kind of emotion, I end up thinking that the product is connected to a feeling.

This result confirms the perspective that affective activation is more recurrent when there are visual stimuli, such as Instagram images, as they are intrinsic to emotional appeals that occur unintentionally and less rationally (Tate et al., 2014; Minton et al., 2016). Therefore, feelings and emotions that most affect users were identified, namely: desire for immediate possession, social comparison, imaginative envy, happiness and sense of belonging.

According to the interviewees, the most recurrent feeling after the stimulus is displayed is that of immediate possession. About this, it is noted that users, when viewing the posts, feel the immediate desire to own the product or service shown in the image, even 
making the purchase quickly. "I have already made an impulse purchase, right after when I saw a post. It happened at the moment the person posted it, then I immediately accessed the site, selected what I wanted, processed the payment and that's it. It is that simple. The experience is generally good and that sucks, because you end up doing it over and over again." (Interviewee 21_BA). Therefore, this report confirms that there is a quickness in the user's decision making when interested in the product, characterized as an impulse purchase (Badgaiyan \& Verma, 2015).

The other feeling identified was that of social comparison between users and their virtual contacts. For the interviewees, this comparison occurs when they observe people in situations superior to theirs, when they see the image, as Interviewee 6 reports: "Most of the time I see that photo when I am in a very boring place, like a classroom, work, home, then you want to be in that person's position, regardless of where they are, you just don't want to be where you are". This result is in agreement with Liu et al., (2018), when they refer to the feeling of social comparison that arises from the desire to imitate the qualities of those that users interpret as superior targets, and from that point on consumption is boosted.

This social comparison is not a feeling that occurs in isolation, triggering other feelings to which they are linked, such as that of imaginative envy. In this regard, it was possible to perceive that users see their contacts' posts and imagine themselves having the same products, visiting the places they are visiting and experiencing the same adventures that they are living and showing through their posts, as detailed by Interviewee 24_TO:

I can say that if I could I would make all the trips that my friends did. Honestly, I really want to go, to share, to be in the same places they were in, the good places, and at the time I feel this "white envy", so to speak. If I see a picture of a friend of mine there in Fortaleza, at the beach, eating shrimp, drinking beer, of course I will want to be there. Now I can't, but when I can, I'll want to go there, too. I think this is quite normal to happen.

It is understood, then, that consumers are more likely to feel envy when exposed to the publications of their peers, especially when referring to locations, reaffirming that images of friends and personalities in their travel moments attract even more users' attention, leading them to aspire to that same situational context and then purchase the service (Gössling \& Stavrinidi, 2016; Liu et al., 2018).

The feeling of happiness arises in the same aspirational context, since users feel the joy that friends express in their photos and search for products and services that are associated with this feeling (Interviewee 33_RN). The presence of this feeling reinforces the understanding that users want to follow the pattern of happiness that is published on 
Instagram, especially by famous personalities, and for that, they choose a consumption similar to theirs (Jacob, 2014).

At the end, there is the feeling of belonging. We notice that it is related to the user's personal satisfaction of being part of a particular social group (Interviewed 31_AM), targeting the status and acceptance of the virtual contacts when also purchasing the product or service posted (Santos et al., 2017).

In addition to affective activation, the presence of activation motivated by behavioral intentions was also identified, namely, when information is already stored in the user's memory about the product/service, but its consumption is only activated upon exposure of the stimulus, as Interviewee 10_SC commented: "Most of the time I have already seen the product in the supermarket or drugstore, but only after seeing a post of someone using it, I remember it and decide to give it a try". Thus, it can be said that, in this case, there was already a pre-existing goal or interest to purchase and the post acted to propel the action through a "boost", confirming the studies by Pacheco Junior et al. (2015) and Minton et al. (2016).

In the sequence, social activation is identified as another form of activation found in the participants' responses. In this regard, it is understood that users are attracted by the content of profiles that have a certain representation on Instagram. The relationship with these people is one of admiration, trust and inspiration, which facilitates the processing of information and leads to further actions, such as adopting a certain lifestyle, a dressing style or behaving, as detailed by Interviewee 5: "sometimes we are practicing some sport and a person you follow is also doing it, so you end up doing the same exercises this person is doing, follow a diet and buy healthy things. It is not that you want to be that person, but since you follow them you end up absorbing some habits they have". This strengthens the literature by confirming that social representations can also be considered an activating and influencing stimulus of consumption (Dijksterhuis et al., 2006; Pacheco Junior et al., 2015).

On the other hand, cognitive activation was perceived less frequently in the interviewees' speech, but it is understood that it is important, especially in the context of social networks in which individuals feel more secure to report their consumption experiences. In this case, it is noticed that users are exposed to suggestions that help their judgments and clarifications regarding products and services (Interviewee 18_MA and Interviewee 22_AC), reinforcing the understanding of change in thinking/perception proposed by Minton et al. (2016). 
It is understood that the different forms of activation can occur in all resources available on Instagram, however, there is a greater incidence in photo postings and in the Insta stories function, due to the fact that they are visual publications. As previously mentioned, this happens due to the visual excitement that photographs and videos cause in users, making them pay more attention to this type of content (Hsu, 2015; Jin \& Ryu, 2019) and, consequently, they are more likely to have the consumption enabled.

Thus, in this specific case of Instagram, it was possible to identify a relationship between the publications of the followed contacts with emotions, behavioral intentions, social representations and changes in users' thoughts, confirming that the consumption activation process happens through associations between a stimulus and the ideas related to it (Fazio et al., 1986).

\section{Final considerations}

From the general objective of identifying the positive and negative attributes of Instagram posts and their ways of activating consumption, the presence of attributes related to aesthetics, presentation, authenticity, affinities and information is identified. Therefore, it can be observed that the quality of the content is a prominent aspect to perform the activation of consumption, since it is perceived that users value quality images and positive content, mainly because Instagram is a social network for sharing information, images and visual exposure, which contributes to aesthetics being taken into account. It is important to emphasize that quality must not exceed the limits of reality, especially that posts do not need to be manipulated in a way that they become different from reality, otherwise the content will be rejected and the purchase decision compromised.

It is also noticed that another factor responsible for generating both positive and negative activation is formed by the information or even the lack of it, which allows us to understand that users are more attracted to publications that contain complementary information about the product, such as price, advantages and reports with real experiences. This happens due to the practicality and ease that the subjects seek when obtaining consumption information on the virtual social network.

Therefore, the findings led us to reach the research objective by investigating the positive and negative attributes of Instagram posts. However, this investigation ended up going further and found that users' consumption can be activated through different ways, such 
as emotions, behavioral intentions, social representations and change of thought, as long as there is prior interest and affinity of users with what is being published.

It is observed that the theoretical contribution of this study is to provide a discussion about the activating attributes of Instagram publications and their effects on the subjects' consumption decisions, from the perspective of the priming effect, a theory that is still little addressed in studies involving the consumer behavior. Then, this article will assist future investigations involving digital social networks and incentives favorable to consumption.

On the other hand, the results obtained also contribute for companies and professionals working in the digital sector to pay attention to the feelings, emotions, perception and actions that are generated by the dissemination of products/services, as well as their positive influences on the public's behavior. Furthermore, at the time when social networks are present in the lives of consumers, in order to assist in the elaboration of strategies, it is essential that companies know the stimuli in this virtual environment and how users react.

One of the research limitations is the little explored literature on priming virtual and stimuli that lead users of social networks to make a purchase action. It is believed that previous researches on this topic could have helped to better support the results. As a suggestion for future studies, an in-depth analysis explaining how the consumption activation process occurs in the user's mind when viewing the stimuli exposed on Instagram may be a good research topic. In addition, it is recommended that studies highlight the profiles that can contribute to strengthen this process, taking into account that people are also activating stimuli.

\section{References}

Alhidari, A., \& Paswan, A. (2015). Personal level antecedents of eWOM and purchase intention, on social networking sites. Journal of Customer Behaviour, 14(2), 107-125.

Almeida, N. M. (2016). Comportamento do consumidor: a influência do smartphone no processo de decisão do consumidor. Dissertação (Mestrado em Administração). Escola de Administração, Universidade Federal da Bahia, Salvador, BA, Brasil, 25p.

Astuti, B., \& Putri, A. P. (2018). Analysis on the Effect of Instagram Use on Consumer Purchase Intensity. Review of Integrative Business and Economics Research, 7(2), 24-38.

Badgaiyan, A. J., \& Verma, A. (2014). Intrinsic factors affecting impulsive buying behavior: Evidence from India. Journal of Retailing and Consumer Services, 21(1), 537-549.

Bardin, L. (2011). Análise de Conteúdo. Lisboa: Edições 70. 
Boyd, D. M. \& Ellison, N. B. (2008). Social Network Sites: Definition, History, and Scholarship. Journal of Computer-Mediated Communication, 13(1), 210-230.

Cooper, D. R., \& Schindler, P. S. (2011). Métodos de pesquisa em administração. $10^{\mathrm{a}}$ ed. Porto Alegre: Bookman.

Chu, S. \& Kim, Y. (2011). Determinants of consumer engagement in electronic word-of-mouth (eWOM) in social networking sites. International Journal of Advertising, $30(1), 47-75$.

Damayanti, E., \& Pamungkas, I. N. A. (2018). Digital marketing content through warteg hipster instagram as efforts to build brand awareness. e-Proceeding of Management, 5(1), 1333-1340.

Dijksterhuis, A., Smith, P. K., Baaren, R.B., Vwigboldus, D. H. J. (2006). The unconscious consumer: effects of environment on consumer behavior. Journal of Consumer Psychology, 15(3), 193-202.

Di Pietro, L., Pantano, E. (2012). An empirical investigation of social network influence on consumer purchasing decision: The case of Facebook. Journal of Direct, Data and Digital Marketing Practice, 14(1), 18-29.

Djafarova, E., \& Rushworth, C. (2017). Exploring the credibility of online celebrities' Instagram profiles in influencing the purchase decisions of young female users. Computers in Human Behavior, 68(1), 1-7.

Fazio, R. H., Sanbonmatsu, D. M., Powell, M. C., \& Kardes, F. R. (1986). On the Automatic Activation of Attitudes. Journal of Personality and Social Psychology, 50(2), 229-238.

Ferreira, E., Constantino, F. A., \& Lima, J. S. (2017). Cotidiano e Instagram: efemeridade e narrativas de si no recurso Stories. Esferas, 6(11), 151-161.

Godoy, A. S. (1995). Introdução à pesquisa qualitativa e suas possibilidades. Revista de Administração de Empresas, 35 (2), 57-63.

Gomes, R. A. (2001). Análise de dados em pesquisa qualitativa. In: MINAYO, M. C. de S. (Org.) Pesquisa Social. Teoria, método e criatividade. 18. ed. Petrópolis: Vozes.

Gössling, S., \& Stavrinidi, I. (2016). Social Networking, Mobilities, and the Rise of Liquid Identities. Mobilities Journal, 11(5), 723-743.

Hermida, A., Fletcher, F., Korrell, D., \& Logan, D. (2011). Your Friend as Editor: The Shift to the Personalized Social News Stream. Anais do The Future of Journalism Conference. Cardiff: Cardiff University.

Hu, Y., Manikonda, L., \& Kambhampati, S. (2014). What We Instagram: A First Analysis of Instagram Photo Content and User Types. Anais do Eighth International AAAI Conference on Weblogs and Social Media, Michigan, USA, 595-598.

Hsu, C. (2015). The influence of cognitive and affective priming on banner ad attention and effect. Anais do 4th International Conference, Bangkok, Thailand, 36-41. 
Ioanăs, E., \& Stoica, I. (2014). Social Media and its Impact on Consumers Behavior. International Journal of Economic Practices and Theories, 4(2), 295-303.

Jacob, H. (2014). Redes sociais, mulheres e corpo: um estudo da linguagem fitness na rede social Instagram. Revista Communicare, 14(1), 88-105.

Jin, S. V., \& Ryu E. (2019). Instagram fashionistas, luxury visual image strategies and vanity. Journal of Product \& Brand Management, 1(1), 1-14.

Kreft, J., \& Karwat, Z. (2017). The Opinion of Facebook Friends as the Most Reliable Recommendation of Products and Services in Poland: The Evolution of Purchase Pathways in Social Media. Handel Wewnętrzny, 5(370), 250-259.

Kusumah, R. (2015). Analyze The Effect Of Trust, Price, Quality And Perceived Risk Toward Consumer Purchase Behavior In Online Shops Instagram. Journal Berkala Ilmiah Efisiensi, 15(5), 355-366.

Leite, Y. V. P., Moraes, W. F. A. de., \& Salazar, V. S. (2016). Teoria adaptativa e ATLAS.ti 7: uma parceria para o desenvolvimento de framework de empreendedorismo internacional. Revista Gestão \& Tecnologia, 16(2), 153-176.

Liu, H., Wu, L., Li, X. (2018). Social Media Envy: How Experience Sharing on Social Networking Sites Drives Millennials' Aspirational Tourism Consumption. Journal of Travel Research, 1(1), 1-15.

Mashhadi, M., \& Hashemiamin, A. (2017). The impact of corporate social responsibility indicators on consumer behavior: a case study: electronic and quasi-electronic customers of persian carpet co. Revista QUID, 1(1), 2516-2528.

Meurer, A. M., Medeiros, J. F., Dal'maso, C. B., \& Holz, G. (2010). Grupos de Referência e Tribos Urbanas: Um Estudo junto a Tribo "Emo". Anais do Encontro De Marketing Da Anpad, Florianópolis, 1-17.

Minayo, M. C. de S. (Org.) (2001). Pesquisa Social. Teoria, método e criatividade. 18. ed. Petrópolis: Vozes.

Minton, E. A., Cornwell, T. B, \& Kahle, L. R. (2016). A theoretical review of consumer priming: Prospective theory, retrospective theory, and the affective-behavioral-cognitive model. Journal of Consumer Behaviour, J. Consumer Behav, 16(4), 1-14.

Miranda, F. J., Rubio, S., Chamorro, A., \& Loureiro, S. M. C. (2014). Using Social Networks Sites in the Purchasing Decision Process. International Journal of E-Business Research, 10(3), 18-35.

Moreira, A. C., Jacques, J. J., \& Pizzato, G. Z. A. (2019). Atributos estéticos e sustentabilidade: estudo de caso com mochilas de marcas gaúchas. Projética, 10(2), 169186.

Nicolao, L., Yorkston, E., Brocato, D., \& Brei, V. A. (2016). Improving Consumer Decisions: The Conscious Use of Primes as Performance Enhancers. Brazilian Adnistration Review, 13(1), 19-32. 
Nunes, R. H., Ferreira, J. B., Freitas, A. S. de., \& Ramos, F. L. (2018). Efeitos das recomendações de líderes de opinião em mídias sociais sobre a intenção de compra de seus seguidores. Revista Brasileira de Gestão e Negócios, 20(1), 57-73.

Obar, J., \& Wildman, S. (2015). Social media definition and the governance challenge: An introduction to the special issue. Telecommunications Policy, 39(9), 745-750.

Pacheco Junior, J. C. S., Damacena, C., \& Bronzatti, R. (2015). Pré-ativação: o efeito priming nos estudos sobre o comportamento do consumidor. Estudos e Pesquisas em Psicologia, 15(1), 284-309.

Peppard, J. \& Butler, P. (1998). Consumer purchasing on the internet: Processes and prospects. European Management Journal, 16(5), 600-610.

Primo, Alex. (2007). O aspecto relacional das interações na Web 2.0. E- Compós, Brasília, 9, $1-21$.

Rani, P. (2014). Factors influencing consumer behavior. International Journal Current Research Academic Review, 2(9), 52-61.

Recuero, R. (2009). Diga-me com quem falas e dir-te-ei quem és: a conversação mediada pelo computador e as redes sociais na internet. Famecos, 16(38), 118-128.

Rodrigues, R. C., Araújo, A. F. T. A., Castro, M. C. A. M., \& Castelo, J. S. F. (2019). Top of mind e brand equity das marcas de refrigerante na percepção dos consumidores em redes sociais. Anais do Congresso Latino-Americano de Varejo e Consumo, São Paulo, SP, Brasil.

Silva, J. C. P., \& Rabelo Neto, A. (2018). Determinantes da decisão de compra da baixa renda. Pensamento Contemporâneo em Administração, 12(1), 89-104.

Solomon, M. R. (2016). O comportamento do consumidor: comprando, possuindo e sendo. 12. ed. Porto Alegre: Bookman.

Stake, R. E. (2011). Pesquisa qualitativa: Estudando como as coisas funcionam. Porto Alegre: Penso.

Ting, H., Ming, W. W. P., Run, E. C. \& Choo, S. L. Y. (2015). Beliefs about the Use of Instagram: An Exploratory Study. International Journal of Business and Innovation, 2(2), $15-31$.

Toor, A., Husnain, M., \& Hussain, T. (2017). The Impact of Social Network Marketing on Consumer Purchase Intention in Pakistan: Consumer Engagement as a Mediator. Asian Journal of Business and Accounting, 10(1), 167-199.

Tubenchlak, D. B., Faveri, D. de, Zanini, M. T., \& Goldszmidt, R. (2015). Motivações da Comunicação Boca a Boca Eletrônica Positiva entre Consumidores no Facebook. Revista de Administração Contemporânea, 19(1), 107-126. 
Veirman, M., \& Hudders, L. (2019). Disclosing sponsored Instagram posts: the role of material connection with the brand and message-sidedness when disclosing covert advertising. International Journal of Advertising, 39(1), 94-130.

Walter, S. A., \& Bach, T. M. (2015). Adeus papel, marca-textos, tesoura e cola: inovando o processo de análise de conteúdo por meio do Atlas.ti. Administração: Ensino e Pesquisa, 16(2), 275-308.

Yen, C. (2017). Exploring user's intention to post photos toward social media. Anais do 28th Research World International Conference, Zurich, 26-30.

Yogesh, F., \& Yesha, M. (2014). Effect of Social Media on Purchase Decision. Pacific Business Review International, 6(11), 45-51. 


\title{
NSTAGRAM E SEUS ATRIBUTOS DE CONSUMO: UMA ANÁLISE DE CONTEÚDO
A PARTIR DO EFEITO PRIMING
}

\author{
Maria Naftally Dantas Barbosa \\ Mestre, Universidade Federal Rural do Semi-Árido - UFERSA \\ Mossoró, $\mathrm{RN}$ - Brasil. \\ naftallydantas2@gmail.com \\ Yákara Vasconcelos Pereira \\ Doutora, Professora Adjunta da Universidade Federal de Pernambuco - UFPE \\ Recife, PE - Brasil. \\ yakarav@gmail.com \\ Karla Rosane do Amaral Demoly \\ Pós Doutora em Educação UMINHO PT \\ Professora Associada da Universidade Federal Rural do Semi-Árido - UFERSA \\ Mossoró, RN - Brasil \\ karla.demoly@gmail.com
}

\section{Resumo}

Objetivo: Esta investigação objetivou identificar os atributos positivos e negativos das publicações do Instagram e suas formas de ativação do consumo.

Método: Um estudo de caso foi realizado com os usuários do Instagram em duas etapas: entrevista coletiva e entrevistas individuais. Ao todo, 33 sujeitos participaram das entrevistas semiestruturadas, que foram examinadas por meio da análise de conteúdo com apoio do software ATLAS.ti.

Originalidade/Relevância: Uma investigação sobre o Instagram como uma ferramenta online para influenciar o comportamento do consumidor é necessária, pelo fato de serem ambientes de construção e manutenção do relacionamento social que influencia a sociedade contemporânea.

Resultados: Os resultados revelam que as publicações com imagens de elevada qualidade, pessoas felizes, boa apresentação do produto/serviço, experiências reais e positivas e informações complementares constituem os atributos positivos. Por outro lado, as publicações com imagens não atrativas e sem qualidade, que não correspondem à realidade do produto/serviço ou do usuário, com propaganda disfarçada e sem informações formam os atributos negativos. Ainda, nota-se que as publicações ativaram o consumo de diferentes formas, entretanto, isso apenas ocorreu devido às representações mentais pré-existentes.

Contribuições teóricas/metodológicas: Este artigo trouxe a discussão sobre a temática da ativação do consumo no Instagram, ainda pouco explorada na literatura do comportamento do consumidor. Ademais, retrata características das publicações que conduzem a efeitos positivos e negativos na visão de entrevistados que representaram cada Estado do Brasil.

Palavras-chave: Ativação do consumo. Instagram. Atributos das Publicações. Comportamento do Consumidor.

\section{Como citar}

American Psychological Association (APA)

Barbosa, M. N. D., Pereira, Y. V., \& Demoly, K. R. do A. (jul./set. 2020). Instagram e seus atributos de consumo: uma análise de conteúdo a partir do efeito priming. Revista Brasileira de Marketing - ReMarK, 19(3), 542-568. https://doi.org/10.5585/remark.v19i3.13907. 


\section{Introdução}

Além de facilitar e expandir os espaços de comunicação entre os usuários, as tecnologias de internet têm estimulado o envolvimento do público na observação, seleção, interpretação e compartilhamento das informações (Primo, 2007). Nesse contexto, é por meio da conversação mediada que são estabelecidas trocas informacionais que dão origem às redes sociais da internet ou redes sociais digitais (Recuero, 2009).

Apesar de fazerem parte mais da vida dos jovens, as redes sociais podem influenciar o comportamento de consumo de pessoas com diferentes idades (Harris \& Dennis, 2011), o que torna seu impacto ainda maior. Além disso, essa prática de recomendações, compartilhamento de opiniões e conselhos relacionados ao consumo pode gerar confiança e influenciar negativa ou positivamente a intenção de compra (Tubenchlak, Faveri, Zanini \& Goldszmidt, 2015; Solomon, 2016).

Uma das redes sociais que mais cresce mundialmente é o Instagram (Djafarova \& Rushworth, 2016). O aplicativo foi fundado em 2010 e permite que os usuários capturem e compartilhem imagens e vídeos de maneira instantânea virtualmente. Entre as funções da rede é possível destacar a capacidade dos usuários em adicionar descrições, hashtags, mencionar outros usuários e inserir localizações e links em suas publicações (Hu, Manikonda \& Kambhampati, 2014).

No caso do Instagram, os sujeitos são divididos entre seguidores (perfis que seguem o usuário) e seguidos (perfis que o usuário segue). Esse recurso constitui a rede de contatos do usuário, permitindo que ele seja seguido e siga perfis de conhecidos, personalidades e até mesmo de outras pessoas, as quais se interesse em acompanhar o conteúdo (Hu et al., 2014), podendo curtir as publicações favoritas, fazer comentários e compartilhar conteúdo, inclusive com informações de consumo (Guimarães \& Gouveia, 2015). Dessa forma, entende-se que a rede social em questão facilita a comunicação entre consumidores, aumentando o potencial de compartilhamento de experiências pessoais de consumo em tempo real e em diferentes dispositivos e formatos (Tubenchlak et al., 2015).

Vale salientar que, as recomendações de consumo, bem como a preferência por determinado produto, serviço e marca divulgada via mensagens mediadas pelas redes de relacionamentos têm efeitos significativos nos julgamentos e sobre uma possível decisão de compra dos usuários (Di Pietro \& Pantano, 2012), aspectos que podem contribuir para ativar o consumo. 
O processo de ativação é um aspecto recorrente do efeito priming (Minton, Cornwell \& Kahle, 2016), constituído por táticas de influência e persuasão que desencadeiam determinadas respostas automáticas, conscientes (intencionais) ou inconscientes (nãointencionais) (Dijksterhuis, Smith, Baaren \& Wigboldus, 2006). Pode ser descrito como um conjunto de estímulos externos que levam à ativação de algum conceito, ideia e estereótipos, mediante apresentação de um objeto ou situação específica, provocando nos indivíduos comportamentos subsequentes (Fazio, Sanbonmatsu, Powell \& Kardes, 1986; Martin \& Morich, 2011). Sobretudo, os efeitos priming podem ser responsáveis por ativar ou alterar a percepção e o comportamento dos consumidores, bem como suas atitudes e crenças por meio de fatores dentro e fora do controle consciente.

Ademais, destaca-se que a ativação pode proporcionar ao usuário duas percepções a respeito do estímulo: positiva, quando o usuário se identifica com a publicação e deseja estar alinhado às características do que está sendo exposto; ou negativa, quando não há uma identificação com a publicação, fazendo com que o usuário evite as características do estímulo (Galvão, Lucena \& Prado, 2016). Com isso, reforça-se a ideia de que os atributos das imagens publicadas no Instagram podem ser determinantes para aumentar ou comprometer a popularidade, reconhecimento e confiança dos produtos e marcas (Jin \& Ryu, 2019), facilitando as decisões de compra dos usuários.

Apesar de ser um assunto pertencente ao contexto atual da sociedade, é incipiente a quantidade de pesquisas que abordam os aspectos persuasivos presentes nas publicações do instagram que influenciam o comportamento dos consumidores, porém é fundamental a ampliação de estudos sobre a temática (Veirman \& Hudders, 2019). De forma geral, uma investigação sobre o Instagram como uma ferramenta online para influenciar o comportamento do consumidor é oportuna e necessária, pelo fato dessa plataforma ser atualmente um ambiente de construção e manutenção do relacionamento social e envolvimento de consumidores, e que, por esses motivos, podem estimular a ativação do consumo dos usuários (Chu \& Kim, 2011).

Com isso, busca-se preencher essa lacuna teórica e para tornar esses aspectos conhecidos, apresentando também a forma como os usuários respondem às publicações visualizadas e como podem afetar as decisões de consumo. Diante disso, esta investigação possui o objetivo de identificar os atributos positivos e negativos das publicações do Instagram e suas formas de ativação do consumo. 


\section{Referencial teórico}

Nesta seção, são desenvolvidas as bases teóricas que foram usadas como pilares para o desenvolvimento deste estudo.

\subsection{Comportamento do consumidor em redes sociais digitais}

Os estudos que envolvem o comportamento do consumidor estão sendo constantemente abordados nas últimas décadas, por ser uma área que está sempre em evolução na medida que novos hábitos, estilos de vida e formas de interação surgem (Solomon, 2016). O comportamento do consumidor é um campo que estuda os comportamentos de compra (Rani, 2014), abordando as atividades mentais, físicas e emocionais dos sujeitos envolvidos no processo de consumo (Mashhadi \& Hashemiamin, 2017), bem como as ações e experiências individuais que podem vir a influenciar a tomada de decisão (Badgaiyan \& Verma, 2015; Silva \& Rabelo Neto, 2018) e satisfazer conscientemente as suas necessidades.

O comportamento do consumidor não se limita apenas ao momento da compra, quando há a troca do valor pela mercadoria. O entendimento é mais amplo e envolve todo processo de consumo, incluindo aspectos que influenciam o consumidor antes, durante e depois da compra (pré-compra, compra e pós-compra). Nota-se que para melhor compreender o consumidor, é preciso conhecer o contexto em que vive e o ambiente no qual está inserido, como os aspectos que envolvem as comunidades (Solomon, 2016, Silva \& Rabelo Neto, 2018), a exemplo da influência da internet.

Com a propagação da internet, as ferramentas de comunicação online se expandiram, ampliando a disponibilidade de troca de informações e facilitando a construção de relacionamentos e socialização entre os usuários (Peppard \& Butler, 1998). Esse fenômeno tomou proporção ainda maior com o aparecimento das comunidades virtuais, lançadas no ano de 1997, ao possibilitar que os utilizadores passassem a expressar suas opiniões e tomar decisões de compra (Boyd \& Ellison, 2008). Todavia, essas mudanças não ocorreram apenas na interação entre os consumidores, mas também entre potenciais compradores, estimulando o diálogo entre pares (Ioanăs \& Stoica, 2014) de forma mais rápida, acessível e instantânea.

Especificamente no Instagram, nota-se que a ferramenta de compartilhamento de fotos faz com que a rede social seja a preferida dos consumidores para partilhar (Alhidari \& Paswan, 2015; Ting, Ming, Run \& Choo, 2015), uma vez que as publicações com fotos de produtos permitem que os usuários adquiram informações antes de tomar uma decisão 
(Kusumah, 2015), reduzindo o risco percebido ao realizar uma compra (Djafarova \& Rushworth, 2016).

É importante esclarecer que essas publicações possuem alguns atributos estéticos que podem ser responsáveis por acelerar o processo de consumo por parte dos usuários, ao considerar que a aparência de uma imagem publicada em redes sociais está relacionada diretamente ao aumento do desejo de compra e, consequentemente, ao sucesso do produto ou serviço que está sendo exposto (Moreira, Jacques \& Pizzato, 2019).

Por sua vez, define-se por atributos, as características simbólicas e físicas de um determinado produto ou situação capazes de satisfazer ou não as expectativas do consumidor (Rodrigues, Araújo, Castro \& Castelo, 2019). Nesse caso, compreende-se que os atributos das publicações podem estimular o processo de ativação positiva ou negativa do consumo. Esse processo de ativação está relacionado ao efeito priming, teoria retratada no tópico seguinte.

\subsection{Efeito priming}

Os seres humanos são constantemente influenciados pelo ambiente social em que vivem, as pessoas com quem convivem e os objetos que possuem. Como consequência, essas exposições podem afetar o comportamento dos indivíduos, encorajando-os a realizarem uma reação subsequente como resposta ao estímulo (Pacheco Junior, Damacena \& Bronzatti, 2015; Solomon, 2016). Esse processo de reação é chamado de priming.

Na perspectiva do comportamento do consumidor, Solomon (2016, p. 58) destaca que o priming faz parte da tomada de decisão habitual do consumidor, que se refere "[...] às escolhas feitas com pouco ou nenhum esforço consciente". Esse processo ocorre por meio de associações entre um estímulo e a fatores relacionados a ele (Fazio et al., 1986), ou seja, quando um indivíduo é exposto a um estímulo específico, como imagens que fazem referência a produtos e marcas, é ativada automaticamente a ideia de consumo, fazendo com que assuma comportamentos subsequentes. Esses comportamentos podem ser o ato de realizar a compra do produto, em casos de ativação positiva ou a rejeição do produto, em casos de ativação negativa (Galvão et al., 2016).

Os efeitos priming podem exercer influência na formação do comportamento, percepções e julgamentos dos indivíduos, mesmo que não sejam percebidos. Esses fatores podem ser visuais, auditivos, olfativos e podem ativar temporariamente uma tendência de resposta (Tate, Stewart \& Daly, 2014; Nicolao, Yorkston, Brocato \& Brei, 2016). Diante 
disso, o priming ocasiona numa ativação por meio de três formas, quais sejam: afetiva ou emotiva; comportamental ou motivacional; e cognitiva ou semântica.

O priming afetivo envolve estímulos não intencionais, como sentimentos e emoções relacionadas a uma ideia. Na maioria das vezes o efeito ocorre com imagens e cores, como por exemplo, símbolos relacionados ao amor e cores que representam a alegria. Além disso, as imagens são responsáveis por produzir mais estímulos afetivos do que as palavras, isso porque apelam para os sentidos e menos à racionalidade (Tate et al., 2014; Minton, Cornwell \& Kahle, 2016).

O priming comportamental envolve intenções comportamentais que são ativadas por meio de informações que ficam mantidas na memória e apenas são associadas quando o indivíduo se depara com o objeto ou contexto (Pacheco Junior et al., 2015). Um exemplo disso, no contexto do comportamento do consumidor, é a motivação que um indivíduo recebe para realizar uma ação de compra de um produto de alta qualidade e socialmente aceito logo após ver o logotipo da Apple ou quando passa a ter hábitos mais saudáveis ao ser constantemente exposto a propagandas de academia ou cartazes com receitas vegetarianas (Minton et al., 2016).

Por último, o priming cognitivo refere-se às mudanças de pensamento com base na presença de um estímulo. É também conhecido como uma ativação semântica, pois pode ser impulsionada por palavras, frases, sinais, símbolos, que influencia uma resposta/ação. Nos campos de estudos do marketing e comportamento do consumidor, a ativação cognitiva e semântica é utilizada para medir o que o consumidor pensa depois de ter sido exposto a um estímulo (Minton et al., 2016), ou seja, a avaliação do consumidor a respeito da marca ou produto e suas experiências pessoais.

Outro tipo é mencionado por Pacheco Junior et al. (2015) e Dijksterhuis et al. (2006), o priming social, constituído por representações sociais de pessoas e pode ser considerado como um estímulo ativador. Nesse caso, pessoas associadas a outras podem levar a ativação automática de uma ação, como por exemplo, ao observar o comportamento de parentes, amigos e pessoas importantes, o indivíduo começa a agir como essas pessoas e ter os mesmos hábitos de consumo (Dijksterhuis et al., 2006; Meurer, Medeiros, Dal'maso \& Holz, 2010).

Ainda é importante esclarecer que um estímulo sozinho não é capaz de gerar uma ação, sendo preciso que haja representações mentais pré-existentes para que a ideia seja ativada (Galvão et al., 2016), ou seja, o indivíduo já deve ter o interesse de consumo internalizado para que seja, de fato, ativado após a exposição. Nesse sentido, o Instagram 
pode influenciar a ativação do consumo por meio de diferentes tipos de publicações, como imagens, vídeos e comentários. Para confirmar esse pensamento, Mirsch, Lehrer e Jung (2017) analisaram fotos de usuários da rede social e constataram que imagens publicadas por perfis seguidos compartilhando momentos, opiniões, demonstrações de produtos e recomendação de marcas podem ativar o interesse do consumidor, estimulando-o a tomar a decisão de consumir, como será abordado no tópico a seguir.

\subsection{Atributos ativadores}

Outro aspecto importante que deve ser discutido é em relação aos diferentes tipos de publicações que o Instagram fornece, como imagens, vídeos e comentários, podendo influenciar a ativação do consumo. Esses conteúdos gerados pelos usuários são o que alimentam a rede diariamente e a torna atraente (Obar \& Wildman, 2015). Em redes sociais como o Instagram, cada usuário possui uma timeline considerada como um espaço contendo uma lista atualizada das suas principais conexões de interesse, como as publicações e compartilhamentos de conteúdo dos perfis que seguem (Ferreira, Constantino \& Lima, 2017).

Os principais recursos disponíveis no Instagram incluem os comentários, compartilhamento de fotos, recurso de localização, além das publicações em formato de vídeos (Yen, 2017), como serão melhor abordadas a seguir.

A interconectividade entre os consumidores de redes sociais como o Instagram é demonstrada por meio de comentários (Astuti \& Putri, 2018). Sobre esse recurso, Gössling e

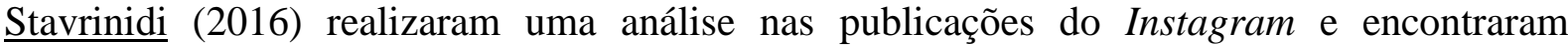
comentários com mensagens curtas e positivas, na maioria das vezes, transmitindo admiração e desejo de também adquirir o que foi publicado pelos contatos seguidos. Isso sugere que, comentários com declarações sobre produtos e serviços no Instagram podem desenvolver nos usuários uma atitude positiva e comportamento favorável ao consumo (Miranda, Rubio, Chamorro \& Loureiro, 2014; Djafarova \& Rushworth, 2016; Kreft \& Karwat, 2017), tendo em vista que os usuários estarão mais propensos a comprar depois de ler comentários positivos (Yogesh \& Yesha, 2014).

Compreende-se que o recurso principal do Instagram é a captura e compartilhamento de imagens, oferecendo aos usuários a maneira única de postar fotos e vídeos utilizando smartphones e aplicando diferentes ferramentas de manipulação (Hu et al., 2014; Guimarães \& Gouveia, 2015). A foto postagem tem sido uma influente ferramenta na formação da identidade, como forma de se auto revelar, bem como compartilhando experiências e produtos 
novos que adquirem. Foi possível encontrar duas razões para analisar a foto postagem no comportamento dos usuários do Instagram: a primeira está relacionada à excitação visual que as fotografias transmitem aos usuários, sendo capaz de oferecer mais informações do que publicações em texto; já a segunda razão está na necessidade que os indivíduos possuem de expor a sua vida diária nas redes sociais, principalmente com um público mais seleto (Guimarães \& Gouveia, 2015; Yen, 2017). Vale ressaltar que as publicações com imagens nas redes sociais podem ser um estímulo de destaque na ativação do consumo, isso porque a exposição visual de objetos provoca o aumento da percepção de confiança entre os indivíduos, fazendo com que o usuário preste mais atenção ao conteúdo (Hsu, 2015; Jin \& Ryu, 2019).

Sobre o terceiro instrumento, Yen (2017) indica que o recurso da marcação da localização (check-in) em fotos estimula a ação dos usuários, afetando a sua intenção de consumo, principalmente de viagens e restaurantes. É importante enfatizar que essa ação é desencadeada por um consumo aspiracional, que ocorre em decorrência de uma comparação social entre os usuários (Liu, Wu \& Li, 2018), fazendo com que as publicações com marcação de localização junto com alguma fotografia e um atributo do lugar mencionado, despertem "inveja imaginativa" ou "inveja benigna", ou seja, faz com que o observador imagine o contexto situacional e também se interesse em conhecer (Gössling \& Stavrinidi, 2016; Liu et al., 2018). Nesse âmbito, é importante esclarecer que essa inveja só é considerada um sentimento positivo desde que não haja a intenção de gerar competitividade com os perfis seguidos (Liu et al., 2018).

Por fim, em 2016, o Instagram lançou o modo Instastories, um recurso dedicado para que os usuários compartilhem de forma instantânea suas histórias e vivências em forma de fotografias, vídeos e textos (Silva \& Rabelo Neto, 2018). O recurso é conhecido como mensagem efêmera, devido ao fato de estar disponível no perfil do usuário por apenas 24 horas, havendo a necessidade do conteúdo ser constantemente renovado (Ferreira et al., 2017). Essa função também pode ser responsável por despertar a intenção de compra dos usuários ao tornar disponíveis imagens com experimentos de produtos, serviços e marcas de forma espontânea (Damayanti \& Pamungkas, 2018).

Já em relação às especificidades do conteúdo fornecido, constatou-se que a qualidade da informação percebida influencia a intenção de compra dos receptores da mensagem, tornando-se um fator crucial para despertar o interesse, gerar preferências de consumo e aumentar as opções de compra (Toor, Husnain \& Hussain, 2017). Em decorrência do 
Instagram ser uma rede social voltada para imagens, concentra-se no visual e na estética do conteúdo, estimulando os usuários a compartilharem apenas conteúdo positivo (Djafarova \& Rushworth, 2016; Guimarães \& Gouveia, 2015), a exemplo que fotos de seus momentos saudáveis, felizes e fotogênicos (Jacob, 2014), evitando revelar aos outros produtos ao qual não estão satisfeitos. Diante do que foi apresentado, percebe-se que esses fatores presentes nas redes sociais digitais podem contribuir para estimular o desejo de consumo dos usuários da rede por meio das publicações dos perfis que estão seguindo.

\section{Método}

Para esta investigação, optou-se pela pesquisa de abordagem qualitativa, que busca a compreensão de um fenômeno, baseando-se na coleta de informações, interpretação e descrição de sujeitos e o seu contexto (Stake, 2011; Godoy, 1995). De acordo com Cooper e Schindler (2011), a pesquisa qualitativa tem o objetivo de atingir entendimento profundo a respeito de uma situação específica ou da interação entre pessoas (individuais ou grupos) e coisas. Em vista disso, a abordagem está adequada para o estudo, apresentado como justificativa de escolha o fato da investigação ser centrada no comportamento humano, extraindo dados a respeito dos sentimentos, motivações e percepções de cada sujeito estudado e não apenas apresentando um aspecto geral (Cooper \& Schindler, 2011).

Para obter as informações a fim de alcançar o objetivo da pesquisa, optou-se por realizar um estudo de caso, conceituado por Yin (2015) como uma pesquisa empírica, realizada de forma minuciosa e aprofundada sobre um tema contemporâneo. Os estudos de caso se concentram em uma situação, evento, programa (Merriam, 1988) ou fenômenos individuais, grupais e organizacionais mais complexos da sociedade, como por exemplo, o estudo do comportamento de pequenos grupos em particular. Além disso, favorece maior nível de detalhamento das relações entre os indivíduos e do contexto, assim como lidam com informações mais subjetivas e maior riqueza de detalhes (Yin, 2015).

Com isso, o método de estudo de caso é apropriado para esta investigação, por considerar que contribui para facilitar o entendimento sobre processos específicos e examinar com detalhe a resposta do consumidor a um determinado estímulo (Cooper \& Schindler, 2011).

Por se tratar de estudo de caso, foram utilizadas entrevistas semiestruturadas (Copper \& Schindler, 2011) como técnica de coleta de dados, por ser considerada “[...] uma estratégia fundamental da investigação qualitativa" (Godoy, 1995, p. 61). Em vista disso, essa pesquisa 
utilizou dois tipos de entrevistas, sendo realizadas em duas etapas distintas: entrevista em grupo e entrevista individual, com o objetivo de obter informações detalhadas do fenômeno.

Anteriormente ao período de coleta de dados, foi realizado um estudo piloto com dois sujeitos, um natural do Rio Grande do Norte e outro natural do Ceará, no dia 18 de setembro, em Mossoró-RN, com o objetivo de validar e aprimorar os roteiros de entrevistas das duas etapas, elaborados com base no referencial teórico. $\mathrm{O}$ estudo piloto auxiliou nos procedimentos seguintes (Yin, 2015), como reelaboração de questões e inclusão de novos temas a serem abordados (Leite, Moraes \& Salazar, 2016).

É importante destacar que ambas entrevistas seguiram roteiros com perguntas abertas. Os roteiros continham os mesmos questionamentos, entretanto, no roteiro da entrevista individual foram acrescentadas perguntas com teor mais específico. $\mathrm{Na}$ ocasião, os entrevistados foram questionados sobre a relação do Instagram com o seu consumo no geral, os recursos da rede social que mais gostam de visualizar e os aspectos que os levam a se interessar ou rejeitar determinada publicação e o seu conteúdo. Ainda foram perguntados sobre os sentimentos, emoções e comportamentos que são despertados ao visualizarem a postagem e serem expostos ao produto, serviço, pessoa ou informação.

Dessa forma, a entrevista coletiva foi realizada na primeira etapa da coleta de dados, no dia 27 de setembro de 2018, com um grupo de 6 pessoas para obter ampla variedade de informações (Cooper \& Schindler, 2011). A entrevista durou cerca de 1 hora e 24 minutos e foi conduzida por uma das pesquisadoras com o intuito de realizar a mediação e registrar as informações, além disso foram usados dois gravadores que colaboraram na transcrição da entrevista posteriormente.

Para participar da entrevista em grupo foram determinados os seguintes critérios: (a) ser maior de 18 anos e (b) ser usuário da rede social Instagram. Com isso, a entrevista foi composta por 6 sujeitos heterogêneos, isto é, com variedade de opiniões, histórico de vida e comportamentos diferentes (Cooper \& Schindler, 2011), totalizando 3 mulheres e 3 homens, com idades entre 21 e 39 anos, sendo 5 respondentes do Rio Grande do Norte e 1 do Ceará. Todos eram estudantes do curso de Publicidade e Propaganda da Universidade do Estado do Rio Grande do Norte e trabalham na área de comunicação, permitindo o acesso à temática abordada.

Como forma de ampliar as respostas e obter informações mais específicas e detalhadas sobre as experiências dos usuários na rede social Instagram, realizou-se a segunda etapa, constituída por entrevista semiestruturada individual com 27 pessoas originadas de cada 
estado brasileiro, em momentos isolados e horários pré-agendados. Para alcançar todos sujeitos da pesquisa, as entrevistas ocorreram de forma presencial, virtual, via Skype e Whatsapp, e também por telefone, foram gravadas e totalizaram 684 minutos.

Para participar da entrevista individual foram determinados os seguintes critérios: (a) maior de 18 anos; (b) usuário da rede social Instagram; (c) os participantes deveriam ter nascido em diferentes estados brasileiros. O último critério citado foi fundamental para ampliar o estudo do fenômeno em análise. Portanto, foram entrevistados 21 mulheres e 6 homens, com idade entre 18 e 50 anos. Os respondentes ainda possuem diferentes níveis de escolaridade e profissão/ocupação, o que contribui na abrangência e diferenciação das respostas coletadas.

É importante esclarecer que o critério de seleção dos sujeitos foi do tipo bola de neve, que utiliza cadeias de referência dos participantes já existentes (Flick, 2009). Dessa forma, os respondentes da pesquisa indicaram novos contatos de sua rede pessoal com as características desejadas para participar das entrevistas. Já sobre a quantidade exata de participantes das sessões de entrevistas individuais foi definida quando se obteve a saturação das informações, que ocorre quando não há mais novidade nas respostas coletadas (Paiva Junior, Leão \& Melo, 2011). Nesta pesquisa, aconteceu no momento em que o sujeito do último estado foi entrevistado.

Após a fase de coleta de dados foi iniciada a análise, considerada por Gomes (2001) como a etapa de tratamento dos dados e interpretação dos resultados obtidos. Nesta pesquisa adotou-se a técnica de análise de conteúdo para realizar a interpretação dos dados, auxiliando na descrição, inferência e interpretação (Bardin, 2011) dos dados, buscando obter conexões com o referencial teórico abordado na pesquisa.

A análise de questões abertas, como as que foram aplicadas nas sessões de entrevista, ajudaram a entender as relações que os sujeitos mantêm com o objeto de pesquisa, ou seja, as publicações do Instagram (Bardin, 2011). A escolha por esse método de análise se justifica pela necessidade de enriquecer a leitura por meio da compreensão dos significados e por revelar as relações estabelecidas na fala ou escrita dos entrevistados (Cavalcante, Calixto \& Pinheiro, 2014).

Ainda de acordo com Bardin (2011), a análise dos dados foi composta por três etapas fundamentais: pré-análise, exploração do material e tratamento dos resultados. A pré-análise é considerada a fase de organização. Nessa etapa, foi definido o escopo da pesquisa e realizada 
uma releitura do material, para retirar os erros de digitação e vícios de linguagem dos respondentes.

A exploração do material é a fase de administração das decisões tomadas na préanálise. Consiste na leitura aprofundada do material, buscando codificar, classificar e categorizar (Bardin, 2011). É oportuno ressaltar que nessa fase, no momento da codificação, foram levantados alguns construtos para enriquecer a análise. Para isso, foi definido o recorte, que corresponde a escolha das unidades de registro, os quais foram selecionadas palavraschave e os temas recorrentes (Bardin, 2011).

A última etapa corresponde ao tratamento dos resultados obtidos e interpretação. Para Bardin (2011), essa é a fase de tratar os dados de modo que sejam significativos e válidos. Utiliza técnicas qualitativas e/ou quantitativas para ajudar na interpretação, buscando confirmar os pressupostos da pesquisa e alcançar os objetivos inicialmente propostos. Para isso, foram utilizadas, nesta pesquisa, redes para auxiliar na interpretação dos resultados.

Ressalta-se que na etapa de análise dos dados foi utilizado o ATLAS.ti na versão 8, ferramenta que contribui para a realização de pesquisas que aplicam a análise de conteúdo (Walter \& Bach, 2015). Dentre as funcionalidades do ATLAS.ti há o tratamento de elevada quantidade de informações, o que facilita a sua operacionalização e, consequentemente, o trabalho do pesquisador (Leite, Moraes, \& Salazar, 2016), pois torna o processo mais ágil. Com o programa, foi possível acessar as transcrições, analisar, codificar e categorizar as respostas dos entrevistados.

\section{Análise dos resultados}

Esta seção parte do pressuposto que a qualidade do conteúdo publicado desperta o interesse e influencia tanto positiva quanto negativamente a intenção de compra dos receptores (Toor et al., 2017). Com isso, de acordo com as respostas dos entrevistados foi possível elencar os pontos positivos das publicações que ativam o consumo e despertam interesse de compra, quais sejam: publicações com imagens de elevada qualidade; publicações com pessoas felizes; publicações com uma boa apresentação do produto/serviço; publicações com experiências reais e positivas e publicações com informações complementares (ver figura 1). 
Figura 1 - Atributos positivos

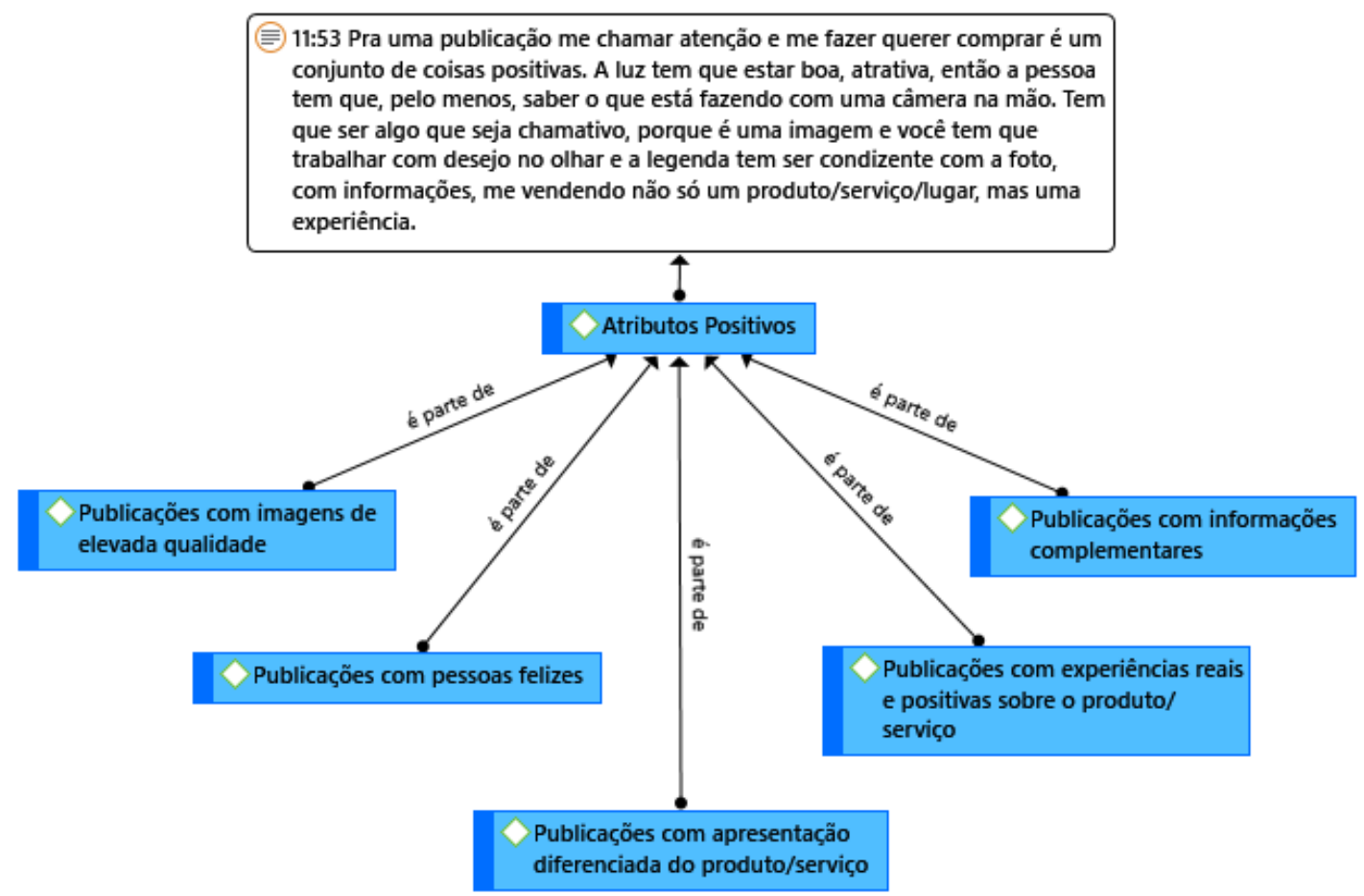

Fonte: Elaboração das autoras com ATLAS.ti (2019).

O primeiro atributo considerado positivo pelos entrevistados é formado pelas publicações com imagens de elevada qualidade. Foram descritas como imagens limpas, organizadas, com cores vivas, alta resolução e nitidez. Esse atributo é considerado ponto forte para atrair a atenção do usuário para a publicação (Entrevistada 6), sendo responsável por vender o conteúdo no primeiro instante (Entrevistada 18_MA), motivando a efetuação da compra (Entrevistado 1 e Entrevistada 5). Com isso, reforça-se a ideia de que as publicações bem elaboradas ativam positivamente o consumo, devido ao fato da exposição visual dos produtos/serviços ser esteticamente atrativa e aumentar o nível de confiança dos usuários (Hsu, 2015; Jin \& Ryu, 2019).

Sobre o segundo fator positivo, é possível identificar as publicações com pessoas felizes. Os entrevistados mencionaram que além da imagem atraente, o fato de expressar felicidade também é um atributo que desperta curiosidade e desejo de estar em conformidade com essa característica, como relata a Entrevistada 20_AL: "Uma imagem bem nítida, colorida e se a pessoa estiver na foto eu reparo muito o semblante dela, se ela está feliz, se é um momento de diversão. Então, o modo como a pessoa está na foto também me chama a atenção". Esse resultado reafirma o pensamento dos autores, no que se refere ao conteúdo positivo compartilhado pelos usuários, isto é, fotos de momentos felizes dos contatos seguidos 
possuem maior impacto, pois geram nos usuários a necessidade de adquirir o mesmo produto ou visitar o mesmo lugar no intuito de seguir o padrão de felicidade que foi publicado (Jacob, 2014).

O terceiro fator mencionado se refere às publicações com apresentação diferenciada do produto/serviço. Aqui, o objeto não é apresentado diretamente, mas inserido dentro de um contexto. Sobre isso, foi possível perceber que os usuários estão atentos à forma como o objeto e a pessoa estão expostos na imagem, priorizando a apresentação mais natural, espontânea e autêntica, sem intenção de venda. "Gosto de publicações criativas, em que o produto está exposto de uma maneira diferente. Acho que não é só tirar a foto do produto em si, mas expor em um contexto diferente, natural e não forçado só pra vender ou pra mostrar que tem aquilo.” (Entrevistada 14_MT). Esse relato fortalece a compreensão de Guimarães e Gouveia (2015), pois apesar dos inúmeros recursos de manipulação de imagens disponíveis no Instagram, como os filtros, as fotografias nas redes sociais são uma representação da realidade e, por isso, influenciam os comportamentos dos usuários.

Nota-se que esse atributo está em conformidade com o fator seguinte, que trata das publicações com experiências de consumo reais e positivas. A respeito desse aspecto, observa-se que os usuários buscam por experiências verídicas de pessoas que realmente tenham comprado e utilizado o produto e compartilhem uma história de consumo positiva (Entrevistado 30_GO). Esse achado está em consonância com Miranda et al. (2014), Djafarova e Rushworth, (2016) e Kreft e Karwat (2017), pois entendem que os relatos de experiências de consumo positivas dos perfis seguidos impactam na decisão de compra dos usuários, principalmente daqueles que estão na fase de busca por informações.

Por fim, os entrevistados mencionam as publicações com informações complementares como o quinto fator positivo. Foi relatado que os usuários priorizam publicações com mais informações a respeito do produto/serviço, como preço, horários e endereço, pois facilitam a apreensão do conteúdo e agilizam o processo, como explica a Entrevistada 1: "[...] se for comida eu quero que tenha preço, porque eu gosto de uma coisa mais prática, então se eu sei o preço e o endereço funciona mais para mim, não preciso buscar mais informações, só realizo a compra". Com isso, reforça-se a ideia de que os usuários buscam as publicações dos perfis que seguem para se informar antes de tomar uma decisão, com o interesse de se sentir mais seguro e confiante sobre a compra (Djafarova \& Rushworth, 2016). Esses dados demonstram a importância de redes sociais como o Instagram no 
cotidiano dos consumidores, por encorajar a discussão e a partilha de conteúdos entre os usuários (Alhidari \& Paswan, 2015).

Além dos atributos positivos, nota-se que a ativação pode ocorrer no sentido oposto, fazendo com que o indivíduo queira se distanciar ou evitar as características do estímulo, caso não haja identificação (Galvão et al., 2016). Portanto, foi possível identificar cinco atributos negativos, considerados indesejáveis pelos entrevistados: publicações com imagens não atrativas e sem qualidade; publicações que não correspondem à realidade do produto/serviço; publicações que não correspondem à realidade do usuário; publicações com propaganda disfarçada; e, propaganda sem informações (ver figura 2).

O primeiro aspecto negativo está relacionado às publicações com imagens não atrativas e sem qualidade. Os entrevistados relataram que imagens sem nitidez ou que são esteticamente poluídas, com excesso de informações e apresentação precária do produto não atraem a sua atenção e fazem com que ignorem o conteúdo publicado (Entrevistada 11_CE). Esse dado reforça Jacob (2014), no sentido de que na rede social Instagram há supervalorização de imagens perfeitas de situações almejadas, fazendo com que os usuários relevem qualquer imagem que esteja esteticamente desajustada.

Figura 2 - Atributos negativos

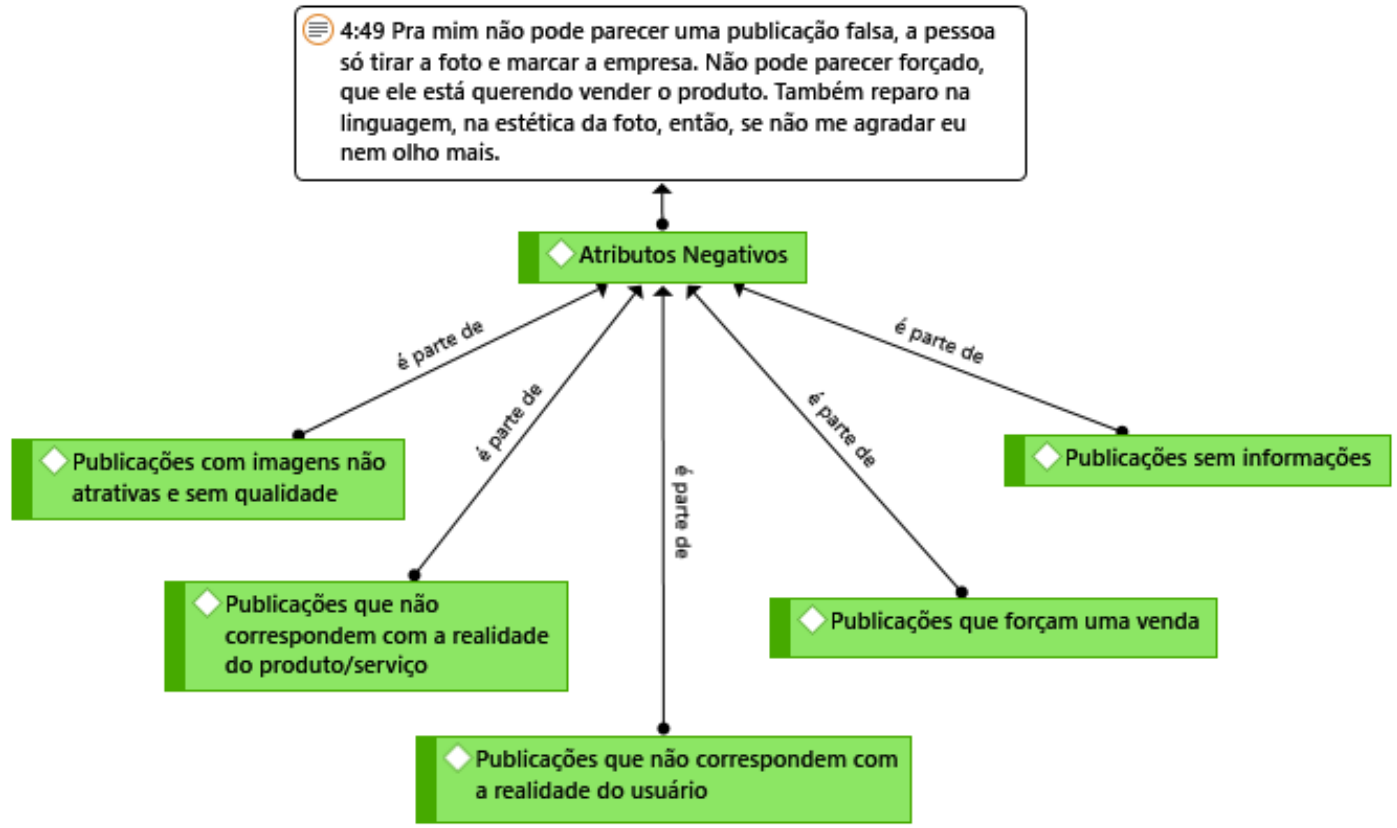

Fonte: Elaboração das autoras com ATLAS.ti (2019).

Outro fator negativo citado pelos entrevistados diz respeito às publicações que não correspondem com a realidade do produto ou serviço, ou seja, publicações que compartilham imagens falsas e enganam os usuários, como detalha o Entrevistada 10_SC: "Eu vejo como 
negativa uma publicação muito editada, fora da realidade, porque às vezes a gente vê um produto no Instagram e quando vai comprar é totalmente diferente do que foi publicado". A esse respeito, entende-se que uma manipulação significativa da imagem pode aumentar o risco percebido no momento da compra, podendo levar o usuário a erro (Djafarova \& Rushworth, 2016), assim faz com que essa publicação seja descartada.

Ainda nesse sentido, foi relatado que as publicações fora da realidade do usuário também são retratadas como um aspecto negativo, isso porque nessas publicações mostram-se produtos que estão fora do orçamento, além de divulgar um estilo de vida diferente do qual vivem os usuários. Esse entendimento é confirmado por meio da opinião da Entrevistada 14_MT:

Eu geralmente perco o interesse quando a foto foge da minha realidade. Quando a pessoa quer mostrar perfeição demais, um corpo perfeito, riqueza, ostentação, às vezes me parece forçado e sem graça. Acaba não chamando minha atenção, porque é fora da minha realidade, eu sei que não irei usar aquele tal produto daquela forma.

Nesse relato foi possível identificar a presença dos grupos dissociativos, os quais os indivíduos não desejam estar associados. Isso porque ao identificar que aqueles que estão seguindo fazem uma publicação que não condiz com sua realidade, valores e comportamentos, os usuários tendem a se afastar e rejeitar o conteúdo, prejudicando o processo de influência (Meurer et al., 2010).

Quanto às publicações com propaganda disfarçada, os entrevistados mencionam como fator negativo aquelas em que as pessoas forçam uma venda, mostrando de forma intensa o produto, o preço e a loja, sem informar os diferenciais do produto e situações as quais poderiam ser úteis (Entrevistada 27_AP e Entrevistado 30_GO). Dessa forma, os resultados estão em consonância com a literatura ao revelar que para que uma mensagem recebida seja aceita, os usuários tendem a analisá-la de acordo com a utilidade da informação e o quanto essa mensagem pode ajudar na decisão, rejeitando qualquer informação forçada, sem argumentos ou credibilidade (Nunes, Ferreira, Freitas \& Ramos, 2017).

Nesse mesmo sentido, foi citado pelos entrevistados que publicações sem descrição do produto e serviço não são bem aceitas, visto que os usuários buscam por informações para realizarem a compra (Miranda et al., 2014; Zucco, Pianezzer \& Falaster, 2017). Portanto, cabe dizer que a publicação, que não acrescenta mais informações que facilite a decisão do usuário, tende a ser ignorada e trocada por outra publicação com conteúdo mais completo, como salienta a Entrevistada 15_DF: "Não gosto de publicação sem nada de informação. Se não tem nada que acrescente, eu paro, olho e sigo adiante para buscar informações em outros lugares". 
Dessa maneira, foi possível observar que as publicações do Instagram influenciam o consumo por meio de diferentes atributos (Mirsch et al., 2017) que podem ativar uma resposta motivada por questões emocionais, comportamentais, cognitivas e pessoais (Tate et al., 2014; Nicolao et al., 2016).

Depois de identificados os atributos positivos e negativos das publicações que realizam a ativação, foi possível verificar os recursos presentes nas publicações que mais atraem os usuários no momento em que há a exposição do estímulo. E ainda, de maneira mais aprofundada, pode-se compreender como ocorre a ativação do consumo no Instagram, e como pode influenciar as emoções, intenções, ações e percepção das pessoas presentes nessa rede social. Na figura 3 consta a rede que explica essa situação, envolvendo as publicações que mais atraem os usuários e as formas de ativação.

O primeiro recurso citado foi a foto postagem, formato que os usuários mais utilizam quando desejam analisar o contexto da imagem, observar os produtos postados, buscar inspirações e tendências, além de acompanhar os perfis que têm interesse e interagir com eles, como explica o entrevistado: "No Instagram eu gosto mais das fotos no feed, porque fica gravado, a gente consegue curtir, comentar, participar do momento, interagir. O que é mais importante nessa rede social é a imagem" (Entrevistado 9_SP). Esse resultado vem para confirmar que o compartilhamento de imagens é o principal recurso do Instagram, tendo em vista que a fotografia proporciona encantamento visual naqueles que visualizam, elevando o nível de desejo pelo que está sendo divulgado (Hu et al., 2014; Guimarães \& Gouveia, 2015; Yen, 2017). 
Figura 3 - Formas de ativação do consumo

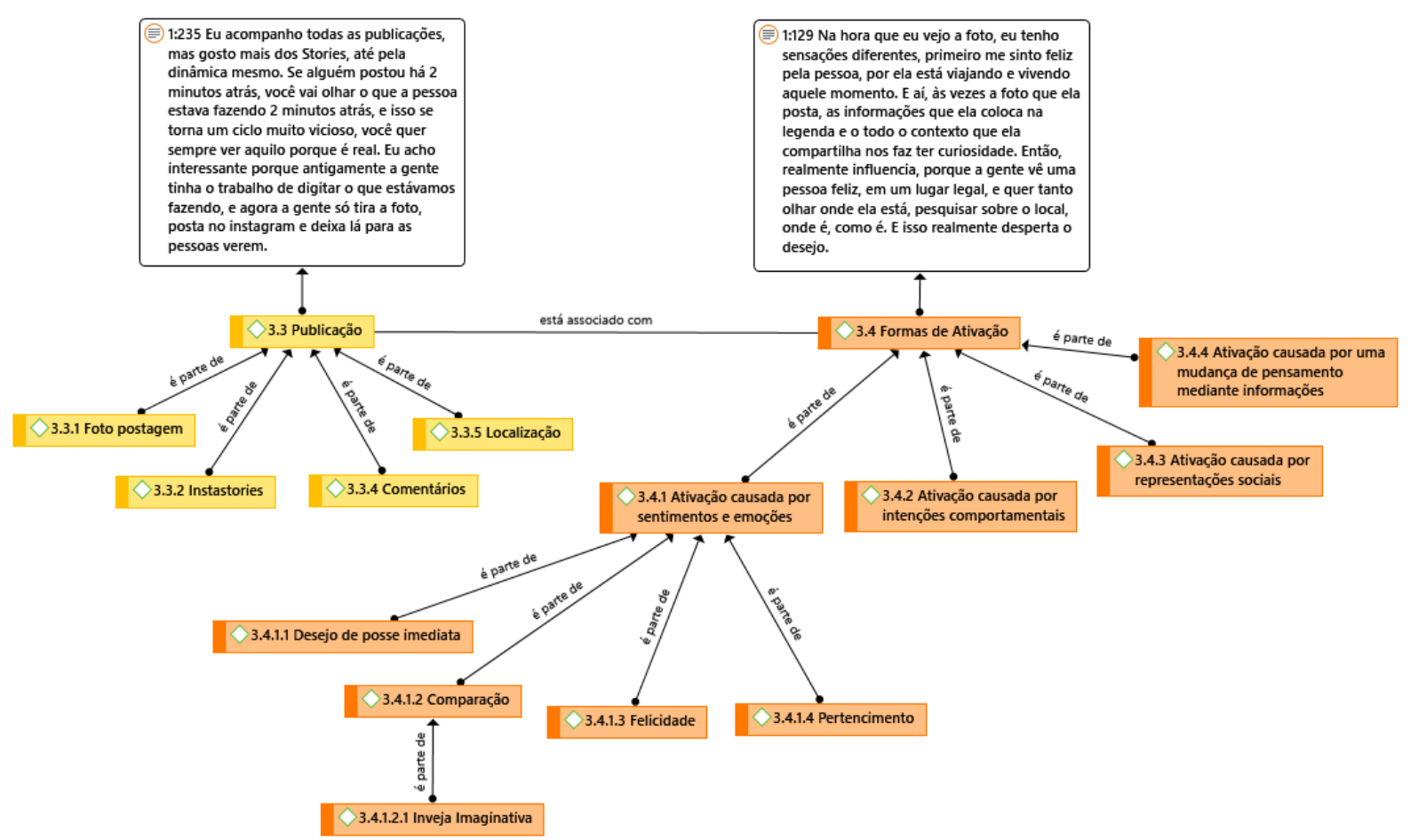

Fonte: Elaboração das autoras com ATLAS.ti (2019).

Por sua vez, o Instastories foi o recurso mencionado mais vezes pelos entrevistados, por ser visto como uma publicação mais dinâmica, rápida e acessível. O diferencial do Stories está em permitir que os usuários acompanhem quase que em tempo real o que as pessoas que seguem estão fazendo, melhorando a interação e a socialização entre eles (Entrevistado 16_SE).

Com isso, percebe-se que por meio do Instastories, os usuários são encorajados a interagir e visualizar novos conteúdos continuamente de seus contatos, isto é, estimula a sentirem a necessidade de estar sempre acompanhando o que estão fazendo, os lugares que frequentam, o alimento que pedem e o que compram, potencializando a intenção de compra devido ao excesso de conteúdo aos quais estão expostos a todo momento (Damayanti \& Pamungkas, 2018). Ainda nesse sentido, os resultados reforçam o pensamento de Ferreira et al. (2017), em relação à confiabilidade no Stories, pois, segundo os entrevistados, esse recurso mostra a vida real de seus contatos virtuais de forma espontânea, contribuindo para aumentar a confiança (Entrevistada 21_BA e Entrevistada 27_AP).

A respeito dos comentários, compreende-se que os usuários costumam observar na opinião das pessoas que comentam nas publicações, como forma de se preparar e se informar antes de realizarem uma compra ou visitarem um lugar específico (Entrevistada 21_BA), 
confirmando a ideia que declarações de contatos virtuais sobre produtos e serviços motivam a atitude positiva ou negativa ao consumo, dependendo da experiência que foi compartilhada na rede social (Djafarova \& Rushworth, 2016; Kreft \& Karwat, 2017).

Já sobre as localizações, os entrevistados dizem se sentir atraídos pelos lugares onde contatos publicam fotos, principalmente se forem desconhecidos. Foi possível perceber que o recurso de marcar a localização se destaca entre os usuários que buscam por informações ou estão predispostos a conteúdos de viagens, como descreve a Entrevistada 14_MT: "Eu amo viajar, então já aconteceu de um amigo postar uma foto em uma cidade bem bonita, que chamou minha atenção, aí eu já fui olhar a localização e da localização, já fui para o Google Maps saber mais informações e me interessei em conhecer o lugar”. Esse achado está de acordo com a literatura, por se tratar de um consumo aspiracional, ou seja, ao ver a foto com a marcação da localização o usuário sente o desejo de também conhecer, desencadeando a ação de compra como consequência (Yen, 2017; Liu et al., 2018).

No que se refere às formas de ativação presentes nas publicações do Instagram, identificou-se a presença da ativação afetiva, comportamental, social e cognitiva. De acordo com as respostas dos entrevistados, nota-se que os usuários são atraídos na maioria das vezes pelas publicações daqueles que seguem devido aos sentimentos que são desencadeados ao serem expostos ao estímulo. Nesse caso, ao verem as imagens, os usuários aspiram estar no lugar de seus contatos, vivenciando a mesma experiência para sentir a sensação de prazer e felicidade que está exposta. Isso influencia o desejo de consumo, levando-os a efetuarem a compra do produto/serviço devido às emoções, como declara o Entrevistado 23_ES:

\footnotetext{
Acho que meus amigos me influenciam pelas sensações que são despertadas ao ver uma publicação, por exemplo, de um tênis novo que você associa aquele tipo de emoção, aquele tipo de experiência que a pessoa está tendo e aí acaba querendo para você também. Então seria mais ou menos esse tipo de emoção, eu acabo sentindo que aquele produto vem atrelado ao sentimento.
}

Esse resultado confirma a perspectiva que a ativação afetiva é mais recorrente quando há estímulos visuais, como as imagens do Instagram, pois estão intrínsecos a apelos emocionais que ocorrem de forma não intencional e menos racional (Tate et al., 2014; Minton et al., 2016). Assim sendo, foram identificados sentimentos e emoções que mais afetam os usuários, quais sejam: desejo de posse imediata, comparação social, inveja imaginativa, felicidade e sensação de pertencimento.

De acordo com os entrevistados, o sentimento mais recorrente após a exibição do estímulo é o de posse imediata. Sobre isso, nota-se que os usuários ao visualizarem as 
publicações sentem o desejo imediato de possuir o produto ou serviço exposto na imagem, chegando a efetuarem a compra de forma rápida. "Já comprei por impulso só ao ver uma publicação. É exatamente quando a pessoa posta, aí quando eu vejo já entrei no site, já coloquei no carrinho, já paguei e pronto. Simples assim. Geralmente a experiência é boa e isso é péssimo, porque você acaba fazendo cada vez mais." (Entrevistada 21_BA). Portanto, esse relato confirma que há uma rapidez na tomada de decisão do usuário ao se interessar pelo produto, caracterizando-se como uma compra por impulso (Badgaiyan \& Verma, 2015).

Outro sentimento identificado foi o de comparação social entre os usuários e seus contatos virtuais. Para os entrevistados, essa comparação ocorre quando observam as pessoas em situações superiores a sua, no momento em que estão visualizando a imagem, como relata a Entrevistada 6: "Na maioria das vezes eu visualizo aquela foto quando eu estou em um local bem chato, tipo sala de aula, trabalho, casa, aí você quer estar na posição daquela pessoa, independentemente de onde ela esteja, só não quer estar onde você está". Esse resultado está de acordo com Liu et al. (2018), quando se referem ao sentimento de comparação social que surge em decorrência do desejo de imitar as qualidades daqueles que os usuários interpretam como alvos superiores, e a partir disso tem o consumo impulsionado.

Essa comparação social não é um sentimento que ocorre isoladamente, desencadeando outros sentimentos aos quais estão atrelados, como por exemplo, o de inveja imaginativa. A respeito disso, foi possível perceber que os usuários veem as publicações de seus contatos e se imaginam possuindo os mesmos produtos, visitando os lugares que frequentam e vivendo as mesmas aventuras que estão sendo publicadas, como detalha o Entrevistado 24_TO:

Posso dizer que se eu pudesse eu faria todas as viagens que meus amigos fizeram. Sinceramente, eu tenho muita vontade de ir, de compartilhar, de estar nos mesmos lugares que eles, lugares bons, e na hora eu sinto essa inveja branca, vamos dizer assim. Se eu ver uma foto de um amigo meu lá em Fortaleza, na praia, comendo camarão, tomando cerveja, é lógico que eu vou querer estar lá. Agora eu não posso, mas quando puder, eu vou querer ir lá também. Eu acho que isso é até normal de acontecer.

Compreende-se, então, que os consumidores são mais propensos a sentir inveja quando expostos às publicações de seus pares, principalmente quando se referem a localizações, reafirmando que imagens de amigos e personalidades em seus momentos de viagens atraem ainda mais a atenção dos usuários, levando-os a aspirar aquele mesmo contexto situacional e realizar a compra do serviço (Gössling \& Stavrinidi, 2016; Liu et al., 2018). 
O sentimento de felicidade surge no mesmo contexto aspiracional, já que os usuários sentem a alegria que os amigos expressam em suas fotos e buscam por produtos e serviços que estejam associados a essa sensação (Entrevistada 33_RN). A presença desse sentimento reforça a compreensão de que os usuários desejam seguir o padrão de felicidade que é divulgado no Instagram, principalmente das personalidades famosas, e para isso, optam por um consumo semelhante aos delas (Jacob, 2014).

Ao final, observa-se o sentimento de pertencimento, nota-se que está atrelado à satisfação pessoal dos usuários de fazer parte de determinado grupo social (Entrevistada 31_AM), almejando o status e a aceitação dos contatos virtuais ao também adquirir o produto ou serviço publicado (Santos et al., 2017).

Além da ativação afetiva, também foi identificada a presença de ativação motivada por intenções comportamentais, isto é, quando já existem informações armazenadas na memória do usuário a respeito do produto/serviço, mas o seu consumo apenas é ativado mediante exposição do estímulo, como comenta a Entrevistada 10_SC: "Na maioria das vezes eu já tenho visto o produto no supermercado ou na farmácia, mas só depois de ver uma publicação de alguém usando, é que eu lembro dele e decido dar uma chance". Com isso, pode-se dizer que nesse caso já havia uma meta ou um interesse pré-existente de compra e a publicação agiu impulsionando a ação por meio de um "empurrãozinho", confirmando os estudos de Pacheco Junior et al. (2015) e Minton et al. (2016).

Na sequência, identifica-se a ativação social como outra forma de ativação encontrada nas respostas dos entrevistados. Sobre isso, compreende-se que os usuários se sentem atraídos pelo conteúdo dos perfis que possuem certa representatividade no Instagram. A relação para com essas pessoas é de admiração, confiança e inspiração, o que facilita o processamento de informações e leva a ações posteriores, como adotar determinado estilo de vida, jeito de se vestir ou de se comportar, como detalha a Entrevistada 5: “Às vezes a gente está praticando algum esporte e a pessoa que você segue também, aí você acaba reproduzindo o exercício, a dieta e comprando coisas saudáveis. Não é que você queira ser aquela pessoa, mas você de tanto acompanhar absorve alguns hábitos iguais aos dela”. Isso fortalece a literatura por confirmar que as representações sociais também podem ser consideradas um estímulo ativador e influenciador do consumo (Dijksterhuis et al., 2006; Pacheco Junior et al., 2015).

Por sua vez, a ativação cognitiva foi percebida com menos frequência na fala dos entrevistados, mas entende-se que é importante, principalmente no contexto de redes sociais em que os indivíduos se sentem mais seguros para relatar suas experiências de consumo. 
Nesse caso, nota-se que os usuários estão expostos a sugestões, auxiliando nos julgamentos e esclarecimentos a respeito de produtos e serviços (Entrevistada 18_MA e Entrevistada 22_AC), reforçando a compreensão de mudança de pensamento/percepção proposta por Minton et al. (2016).

Entende-se que as diferentes formas de ativação podem ocorrer em todos recursos disponíveis no Instagram, entretanto, percebe-se maior incidência na foto postagem e na função instastories, pelo fato de serem publicações visuais. Como foi mencionado anteriormente, isso acontece devido à excitação visual que fotografias e vídeos causam nos usuários, fazendo com que atentem mais a esse tipo de conteúdo (Hsu, 2015; Jin \& Ryu, 2019) e, consequentemente, estejam mais propensos a terem o consumo ativado.

Com isso, nesse caso específico do Instagram, foi possível identificar uma relação entre as publicações dos contatos seguidos com as emoções, intenções comportamentais, representações sociais e mudanças de pensamentos dos usuários, confirmando que o processo de ativação do consumo acontece por meio de associações entre um estímulo e as ideias relacionadas a ele (Fazio et al., 1986).

\section{Considerações finais}

A partir do objetivo geral de identificar os atributos positivos e negativos das publicações do Instagram e suas formas de ativação do consumo, identifica-se a presença de atributos relacionados à estética, apresentação, autenticidade, afinidades e informações. Assim sendo, pode-se observar que a qualidade do conteúdo é um aspecto de destaque para realizar a ativação do consumo, visto que se percebe que os usuários prezam por imagens de qualidade e conteúdo positivo, principalmente pelo Instagram ser uma rede social de compartilhamento de imagens e exposição visual, o que contribui para que a estética seja levada em consideração. Importante frisar que a qualidade não deve exceder os limites do real, sobretudo as publicações não precisam ser manipuladas de forma que fujam da realidade, caso contrário o conteúdo será rejeitado e a decisão de compra comprometida.

Percebe-se ainda que outro fator responsável por gerar a ativação tanto positiva quanto negativa é formada pelas informações ou mesmo a falta delas, o que permite entender que os usuários se sentem mais atraídos por publicações que contenham informações complementares a respeito do produto, como preço, vantagens e relatos com experiências reais. Isso acontece devido à praticidade e facilidade que os sujeitos buscam na hora de obter informações de consumo na rede social virtual. 
Nesse sentido, os achados permitem alcançar o objetivo da pesquisa ao investigar os atributos positivos e negativos das publicações do Instagram. Contudo, esta investigação se propôs a ir além e descobriu que o consumo dos usuários pode ser ativado por meio de diferentes formas, como emoções, intenções comportamentais, representações sociais e mudança de pensamento, desde que haja interesse prévio e afinidade dos usuários com o que está sendo publicado.

Observa-se que a contribuição teórica deste estudo está em proporcionar uma discussão a respeito dos atributos ativadores das publicações do Instagram e seus efeitos nas decisões de consumo dos sujeitos, sob a perspectiva do efeito priming, uma teoria ainda pouco abordada nos estudos que envolvem o comportamento do consumidor. Com isso, este artigo auxiliará investigações futuras que envolvam redes sociais digitais e os estímulos favoráveis ao consumo.

Por outro lado, os resultados obtidos também contribuem para que empresas e profissionais que trabalham no setor digital se atentem aos sentimentos, emoções, percepção e ações que são gerados pela divulgação dos produtos/serviços, bem como as suas influências positivas no comportamento do público. Ademais, ao tempo em que as redes sociais estão presentes na vida dos consumidores, para auxiliar na elaboração de estratégias é essencial que as empresas conheçam os estímulos nesse ambiente virtual e como os usuários reagem.

Como limitação da pesquisa, cita-se a literatura ainda pouco explorada sobre priming virtual e os estímulos que levam os usuários de redes sociais a realizar a ação de compra. Acredita-se que pesquisas anteriores a respeito desse tema poderiam ter ajudado a embasar melhor os resultados. Já como sugestão para estudos futuros, indica-se a realização de uma análise aprofundada explicando como ocorre o processo de ativação do consumo na mente do usuário ao visualizar os estímulos expostos no Instagram. Além disso, recomenda-se estudos que destaquem os perfis seguidos que podem contribuir para fortalecer esse processo, levando em consideração que pessoas também são estímulos ativadores.

\section{Referências}

Alhidari, A., \& Paswan, A. (2015). Personal level antecedents of eWOM and purchase intention, on social networking sites. Journal of Customer Behaviour, 14(2), 107-125.

Almeida, N. M. (2016). Comportamento do consumidor: a influência do smartphone no processo de decisão do consumidor. Dissertação (Mestrado em Administração). Escola de Administração, Universidade Federal da Bahia, Salvador, BA, Brasil, 25p. 
Astuti, B., \& Putri, A. P. (2018). Analysis on the Effect of Instagram Use on Consumer Purchase Intensity. Review of Integrative Business and Economics Research, 7(2), 24-38.

Badgaiyan, A. J., \& Verma, A. (2014). Intrinsic factors affecting impulsive buying behavior: Evidence from India. Journal of Retailing and Consumer Services, 21(1), 537-549.

Bardin, L. (2011). Análise de conteúdo. Lisboa: Edições 70.

Boyd, D. M. \& Ellison, N. B. (2008). Social Network Sites: Definition, History, and Scholarship. Journal of Computer-Mediated Communication, 13(1), 210-230.

Cooper, D. R., \& Schindler, P. S. (2011). Métodos de pesquisa em administração. 10. ed. Porto Alegre: Bookman.

Chu, S. \& Kim, Y. (2011). Determinants of consumer engagement in electronic word-of-mouth (eWOM) in social networking sites. International Journal of Advertising, 30(1), 47-75.

Damayanti, E., \& Pamungkas, I. N. A. (2018). Digital marketing content through warteg hipster instagram as efforts to build brand awareness. e-Proceeding of Management, 5(1), 1333-1340.

Dijksterhuis, A., Smith, P. K., Baaren, R.B., Vwigboldus, D. H. J. (2006). The unconscious consumer: effects of environment on consumer behavior. Journal of Consumer Psychology, 15(3), 193-202.

Di Pietro, L., Pantano, E. (2012). An empirical investigation of social network influence on consumer purchasing decision: The case of Facebook. Journal of Direct, Data and Digital Marketing Practice, 14(1), 18-29.

Djafarova, E., \& Rushworth, C. (2017). Exploring the credibility of online celebrities' Instagram profiles in influencing the purchase decisions of young female users. Computers in Human Behavior, 68(1), 1-7.

Fazio, R. H., Sanbonmatsu, D. M., Powell, M. C., \& Kardes, F. R. (1986). On the Automatic Activation of Attitudes. Journal of Personality and Social Psychology, 50(2), 229-238.

Ferreira, E., Constantino, F. A., \& Lima, J. S. (2017). Cotidiano e Instagram: efemeridade e narrativas de si no recurso Stories. Esferas, 6(11), 151-161.

Godoy, A. S. (1995). Introdução à pesquisa qualitativa e suas possibilidades. Revista de Administração de Empresas, 35(2), 57-63.

Gomes, R. A. (2001). Análise de dados em pesquisa qualitativa. In: MINAYO, M. C. de S. (Org.) Pesquisa Social. Teoria, método e criatividade. 18. ed. Petrópolis: Vozes.

Gössling, S., \& Stavrinidi, I. (2016). Social Networking, Mobilities, and the Rise of Liquid Identities. Mobilities Journal, 11(5), 723-743.

Hermida, A., Fletcher, F., Korrell, D., \& Logan, D. (2011). Your Friend as Editor: The Shift to the Personalized Social News Stream. Anais do The Future of Journalism Conference.

Cardiff: Cardiff University. 
Hu, Y., Manikonda, L., \& Kambhampati, S. (2014). What We Instagram: A First Analysis of Instagram Photo Content and User Types. Anais do Eighth International AAAI Conference on Weblogs and Social Media, Michigan, USA, 595-598.

Hsu, C. (2015). The influence of cognitive and affective priming on banner ad attention and effect. Anais do 4th International Conference, Bangkok, Thailand, 36-41.

Ioanăs, E., \& Stoica, I. (2014). Social Media and its Impact on Consumers Behavior. International Journal of Economic Practices and Theories, 4(2), 295-303.

Jacob, H. (2014). Redes sociais, mulheres e corpo: um estudo da linguagem fitness na rede social Instagram. Revista Communicare, 14(1), 88-105.

Jin, S. V., \& Ryu E. (2019). Instagram fashionistas, luxury visual image strategies and vanity. Journal of Product \& Brand Management, 1(1), 1-14.

Kreft, J., \& Karwat, Z. (2017). The Opinion of Facebook Friends as the Most Reliable Recommendation of Products and Services in Poland: The Evolution of Purchase Pathways in Social Media. Handel Wewnętrzny, 5(370), 250-259.

Kusumah, R. (2015). Analyze The Effect Of Trust, Price, Quality And Perceived Risk Toward Consumer Purchase Behavior In Online Shops Instagram. Journal Berkala Ilmiah Efisiensi, 15(5), 355-366.

Leite, Y. V. P., Moraes, W. F. A. de., \& Salazar, V. S. (2016). Teoria adaptativa e ATLAS.ti 7: uma parceria para o desenvolvimento de framework de empreendedorismo internacional. Revista Gestão \& Tecnologia, 16(2), 153-176.

Liu, H., Wu, L., Li, X. (2018). Social Media Envy: How Experience Sharing on Social Networking Sites Drives Millennials' Aspirational Tourism Consumption. Journal of Travel Research, 1(1), 1-15.

Mashhadi, M., \& Hashemiamin, A. (2017). The impact of corporate social responsibility indicators on consumer behavior: a case study: electronic and quasi-electronic customers of persian carpet co. Revista QUID, 1(1), 2516-2528.

Meurer, A. M., Medeiros, J. F., Dal'maso, C. B., \& Holz, G. (2010). Grupos de Referência e Tribos Urbanas: Um Estudo junto a Tribo "Emo". Anais do Encontro De Marketing Da Anpad, Florianópolis, 1-17.

Minayo, M. C. de S. (Org.) (2001). Pesquisa Social. Teoria, método e criatividade. 18. ed. Petrópolis: Vozes.

Minton, E. A., Cornwell, T. B, \& Kahle, L. R. (2016). A theoretical review of consumer priming: Prospective theory, retrospective theory, and the affective-behavioral-cognitive model. Journal of Consumer Behaviour, J. Consumer Behav, 16(4), 1-14.

Miranda, F. J., Rubio, S., Chamorro, A., \& Loureiro, S. M. C. (2014). Using Social Networks Sites in the Purchasing Decision Process. International Journal of E-Business Research, 10(3), 18-35. 
Moreira, A. C., Jacques, J. J., \& Pizzato, G. Z. A. (2019). Atributos estéticos e sustentabilidade: estudo de caso com mochilas de marcas gaúchas. Projética, 10(2), 169-186.

Nicolao, L., Yorkston, E., Brocato, D., \& Brei, V. A. (2016). Improving Consumer Decisions: The Conscious Use of Primes as Performance Enhancers. Brazilian Adnistration Review, 13(1), 19-32.

Nunes, R. H., Ferreira, J. B., Freitas, A. S. de., \& Ramos, F. L. (2018). Efeitos das recomendações de líderes de opinião em mídias sociais sobre a intenção de compra de seus seguidores. Revista Brasileira de Gestão e Negócios, 20(1), 57-73.

Obar, J., \& Wildman, S. (2015). Social media definition and the governance challenge: An introduction to the special issue. Telecommunications Policy, 39(9), 745-750.

Pacheco Junior, J. C. S., Damacena, C., \& Bronzatti, R. (2015). Pré-ativação: o efeito priming nos estudos sobre o comportamento do consumidor. Estudos e Pesquisas em Psicologia, 15(1), 284-309.

Peppard, J. \& Butler, P. (1998). Consumer purchasing on the internet: Processes and prospects. European Management Journal, 16(5), 600-610.

Primo, Alex. (2007). O aspecto relacional das interações na Web 2.0. E- Compós, Brasília, 9, $1-21$.

Rani, P. (2014). Factors influencing consumer behavior. International Journal Current Research Academic Review, 2(9), 52-61.

Recuero, R. (2009). Diga-me com quem falas e dir-te-ei quem és: a conversação mediada pelo computador e as redes sociais na internet. Famecos, 16(38), 118-128.

Rodrigues, R. C., Araújo, A. F. T. A., Castro, M. C. A. M., \& Castelo, J. S. F. (2019). Top of mind e brand equity das marcas de refrigerante na percepção dos consumidores em redes sociais. Anais do Congresso Latino-Americano de Varejo e Consumo, São Paulo, SP, Brasil.

Silva, J. C. P., \& Rabelo Neto, A. (2018). Determinantes da decisão de compra da baixa renda. Pensamento Contemporâneo em Administração, 12(1), 89-104.

Solomon, M. R. (2016). O comportamento do consumidor: comprando, possuindo e sendo. 12. ed. Porto Alegre: Bookman.

Stake, R. E. (2011). Pesquisa qualitativa: Estudando como as coisas funcionam. Porto Alegre: Penso.

Ting, H., Ming, W. W. P., Run, E. C. \& Choo, S. L. Y. (2015). Beliefs about the Use of Instagram: An Exploratory Study. International Journal of Business and Innovation, 2(2), 1531.

Toor, A., Husnain, M., \& Hussain, T. (2017). The Impact of Social Network Marketing on Consumer Purchase Intention in Pakistan: Consumer Engagement as a Mediator. Asian Journal of Business and Accounting, 10(1), 167-199. 
Tubenchlak, D. B., Faveri, D. de, Zanini, M. T., \& Goldszmidt, R. (2015). Motivações da Comunicação Boca a Boca Eletrônica Positiva entre Consumidores no Facebook. Revista de Administração Contemporânea, 19(1), 107-126.

Veirman, M., \& Hudders, L. (2019). Disclosing sponsored Instagram posts: the role of material connection with the brand and message-sidedness when disclosing covert advertising. International Journal of Advertising, 39(1), 94-130.

Walter, S. A., \& Bach, T. M. (2015). Adeus papel, marca-textos, tesoura e cola: inovando o processo de análise de conteúdo por meio do Atlas.ti. Administração: Ensino e Pesquisa, 16(2), 275-308.

Yen, C. (2017). Exploring user's intention to post photos toward social media. Anais do 28th Research World International Conference, Zurich, 26-30.

Yogesh, F., \& Yesha, M. (2014). Effect of Social. 